\title{
Ecotypic differentiation of mid-Atlantic Quercus species in response to ultramafic soils
}

\author{
Jerry Burgess ${ }^{\mathrm{A}, \mathrm{E}}$, Katalin Szlavecz ${ }^{\mathrm{A}}$, Nishanta Rajakaruna ${ }^{\mathrm{B}, \mathrm{C}}$ and Christopher Swan $^{\mathrm{D}}$ \\ A Department of Earth and Planetary Sciences, Johns Hopkins University, Baltimore, MD 21218, USA. \\ ${ }^{\mathrm{B} C o l l e g e}$ of the Atlantic, 105 Eden Street, Bar Harbor, ME 04609, USA. \\ CUnit for Environmental Sciences and Management, North-West University, Private Bag X6001, \\ Potchefstroom, 2520, South Africa. \\ DDepartment of Geography \& Environmental Systems, University of Maryland, Baltimore County, \\ Baltimore, MD 21250, USA. \\ ${ }^{\mathrm{E} C}$ Corresponding author. Email: jerry.burgess@jhu.edu
}

\begin{abstract}
Spatial heterogeneity of soil conditions combined with intraspecific variation confer site-specific edaphic tolerance, resulting in local adaptation and speciation. To understand the geoecological processes controlling community assembly of woodland tree species on serpentine and mafic soils, we investigated resource gradients and provenance (geographic area of propagule collection) as variables affecting typical representative upland oak (Quercus) species distribution. Accordingly, we conducted a year-long reciprocal transplant experiment in the greenhouse with serpentine and mafic soils, using seedlings of five oak species (Quercus marilandica, Q. stellata, Q. montana, Q. michauxii and Q. alba). All seedlings, regardless of provenance or soil depth, displayed more robust growth in the mafic soils. Soil depth was an important determinant, with all species exhibiting increased growth in the deeper-soil treatments. Fitness surrogates such as stem height, relative growth rate, and leaves per plant were greater when seedlings were grown in their home soil than when they were grown in the non-resident soil, suggesting an ecotypic effect. Mean stomatal conductance and stem growth were positively correlated with soil depth in all treatments. Taken together, the study showed provenancespecific growth responses of oak seedlings to soil type and depth, providing a better understanding of the mechanisms controlling species assembly in woodland communities.
\end{abstract}

Additional keywords: edaphic, intra-specific variation, local adaptation, reciprocal transplant, seedling growth, serpentine.

\section{Introduction}

Habitat specialisation can have significant evolutionary consequences, often contributing to local adaptation (Leimu and Fischer 2008; Yost et al. 2012; Bieger et al. 2014) and speciation (Rajakaruna 2004; Kay et al. 2011). Adaptive differentiation in response to distinct ecological pressures has long been recognised as a driver of species diversification (Darwin 1859; Clausen et al. 1940; Ågren and Schemske 2012). Although Darwin clearly implicated the contribution of adaptation to the process of speciation, recent studies have demonstrated how both divergent natural selection and ecological speciation along environmental gradients can affect phenotypic change and drive the evolution of new species (Linhart and Grant 1996; Geber and Griffen 2003; Kawecki and Ebert 2004; Schluter 2009; Yost et al. 2012).

Within the same climatic region, soils are perhaps the most important and least understood among the many factors influencing the ecology and evolution of plant species (Kruckeberg 1986; Rajakaruna 2004). Edaphic stresses such as salt or heavy metal toxicity, nutrient deficiency, or poor physical properties challenge plant growth and development (O'Dell and Rajakaruna 2011). Edaphic environments are highly heterogeneous and vary over many spatial scales affecting the species' ecology and fitness (Lechowicz and Bell 1991; Wardle et al. 2004; van der Putten et al. 2004; Yost et al. 2012). A strong soil geochemical gradient, derived from geologic juxtaposition of edaphic extremes, can act as an agent of divergent selection resulting in ecotypic differentiation (Ettema and Wardle 2002; Rajakaruna et al. 2003; Baythavong and Stanton 2010). Such edaphic extremes occur in woodlands and forests of the mid-Atlantic piedmont because of geologic and pedologic discontinuities, resulting in nutrient-poor or chemically imbalanced, shallow ultramafic soils adjacent to well developed (deeper) and nutrient-rich mafic soils. The two soil types have marked differences in calcium $(\mathrm{Ca})+$ magnesium $(\mathrm{Mg}): \mathrm{Mg}$ ratios, which are diagnostic differentiators of mafic and ultramafic soils in the Piedmont (Shaw et al. 2001; Burgess 2013). Plant species on these resource bases are likely to employ different mechanisms to cope with the dry, nutrient imbalanced ultramafic soils compared with the more mesic and fertile mafic soils. 
Extreme habitats resulting from edaphic conditions are areas of intense environmental filtering, often leading to a unique set of adaptations suited to the local conditions (Harrison et al. 2006; Cornwell and Ackerly 2009; Siegwart Collier and Mallik 2010; Yost et al. 2012). Often listed as a model system to study evolution and ecotypic adaptation (Harrison and Rajakaruna 2011), ultramafic environments have been the focus of numerous studies on adaptive evolution (Kay et al. 2011; Anacker 2014, and references therein). Environmental filtering is extensive on ultramafic soils because they frequently have low water-holding capacity, contain elevated concentrations of heavy metals such nickel $(\mathrm{Ni})$, chromium $(\mathrm{Cr})$ and cobalt $(\mathrm{Co})$, and are often deficient in essential macronutrients (O'Dell and Rajakaruna 2011). Soil depth and correlated factors such as water-holding capacity have also been suggested as a driver of community assembly in some serpentine areas of the midAtlantic piedmont (Barton and Wallenstein 1997; Burgess 2013). Soil depth and moisture also correlate with productivity and resource availability in serpentine habitats (Whittaker 1954; Davies et al. 2007; Moore and Elmendorf 2011). The importance of these two factors have also been demonstrated in invasive species success in some grasslands (Selmants et al. 2012) and questioned as a driver of invasion success in others (Schedlbauer and Pistoia 2013).

In the eastern North American hardwood forests, the largest tree genus, Quercus (oak), is abundant and also known as a foundation species (Fralish 2004; Ellison et al. 2005; McShea et al. 2007). However, the future of oak forests is uncertain because forests are affected by events such as insect herbivory and pathogen introductions (Grünwald et al. 2012; Bereczki et al. 2014). Other impacts include stressors such as development and extensive logging (Nowacki and Abrams 1992; Lorimer 1993; Abrams 2003; Johnson et al. 2009) and species invasions (Tyndall 1992; Burgess et al. 2015). To address oak performance in serpentine environments, we explored resource gradients and provenance as variables affecting typical representative upland oak species assembly by examining their carbon-allocation strategies and stomatal conductance. We conducted a year-long reciprocal transplant experiment on ultramafic and mafic soils, using seedlings of five oak species (Quercus marilandica Muenchh, Q. stellata Wangenh, Q. montana Willd, $Q$. michauxii Nutt and $Q$. alba L.) found in the mid-Atlantic piedmont. Previous studies of populations of forest trees have shown that populations can survive outside the home site and even thrive in situations void of competition or resource limitations (Heikinheimo 1949; Beuker 1994; Rehfeldt et al. 1999, 2002; Shutyaev and Giertych 2000; Reich et al. 2003). However, intra- and interspecific competition limit the distribution and reproductive success of individual genotypes, with relative fitness often being higher at the local or resident site (Clausen et al.1940; Kawecki and Ebert 2004; Savolainen et al. 2007). In a meta-analysis of plant populations, Leimu and Fischer (2008) found that local plants outperformed non-resident plants at their site of origin $71 \%$ of the time. Contradictory data from Carter (1996) showed that 8 of 10 studies of tree species in the eastern USA have shown growth optima in areas north of their current range and would have higher fitness if grown in a cooler climate. Indeed, the literature contains examples of populations that have a lower relative fitness than do non-resident transplants (Rice and Mack 1991; Hereford and Winn 2008; Bieger et al. 2014) and, in the work of Leimu and Fischer (2008), it was shown that in pair-wise comparisons of local adaptation, local plants outperformed non-resident plants only $45.3 \%$ of the time. Most local-adaptation studies focus on short-lived herbaceous species; thus, work on long-lived species such as trees is important to evaluate whether similar processes are operating. Wright (2007) investigated serpentine adaptation in a 36-year experiment using Pinus ponderosa and concluded that adaptation was evident during longer time spans ( $>2$ years). Branco (2009) documented significant physiological differences between Quercus ilex seedlings collected from serpentine and non-serpentine site, but documented no home-site advantage suggestive of local adaptation.

In the present study, we examined the effect of soil type derived from serpentinite, (ultramafic) and gabbro (mafic) parent material and soil depth on growth of resident (native or local) and non-resident oak seedlings. We hypothesised that owing to their unique adaptations, these oak seedlings will exhibit increased growth rates in mafic and home-site soils. Implicit in this hypothesis is that native serpentine species are more tolerant of shallow, water-stressed and nutrient-deficient and imbalanced conditions than are adjacent non-serpentine species. Species commonly found on harsh substrates will show adaptations to xeric conditions such as strong stomatal control able to maintain gas exchange during stressful conditions and increased belowground biomass allocation (Cornic and Massacci 1996; Hermans et al. 2006). We utilised a reciprocal transplant (introducing organisms from each of two or more environments into the others) experiment to examine whether the resident genotypes exhibit higher relative fitness than do non-resident genotypes. Local adaptation was evaluated using morphological and physiological traits (growth rate, biomass production/allocation) as imperfect fitness surrogates. Elemental concentrations in the foliar tissue were used to evaluate possible coping strategies for seedlings grown in high metalcontent serpentine soils.

\section{Materials and methods}

We employed a factorial design using five tree species, with the main factors being soil type nested within varying soil depths. Seeds from five species of oak (Q. alba, white oak; $Q$. marilandica, blackjack oak; $Q$. michauxii, basket oak; Q. montana, chestnut oak; and Q. stellata, post oak) were used because of their prevalence on serpentine and (or) mafic soils. Throughout the mid-Atlantic, Quercus species can be found on a variety of soil types; typically, $Q$. marilandica and $Q$. stellata predominate on xeric sites or soils derived from serpentinite rock, whereas the widely distributed $Q$. alba, $Q$. montana and Q. michauxii, among others, will occur on both soil types, although at a considerably lower basal area and density on ultramafic soil. Seeds (resident and non-resident) were planted within six treatments that included three levels of soil depth (shallow, $15 \mathrm{~cm}$; medium, $30 \mathrm{~cm}$; and deep, $60 \mathrm{~cm}$ ) and two soil treatments: serpentine (ultramafic) and gabbro (mafic). These depths were chosen as representative of soil depths in serpentine savannas, with the deeper treatment more typical of mature woodlands/forests developed on these soils (Burgess et al. 2015). 


\section{Seed collection and preparation}

Approximately 1500 acorns were hand-collected in 2008 from three areas in the Piedmont of Maryland $(39.387055 \mathrm{~N}$, $76.653156 \mathrm{~W} ; 39.641058 \mathrm{~N}, 76.363564 \mathrm{~W}$; and $39.704034 \mathrm{~N}$, $76.190658 \mathrm{~W})$. Not all oak species were present at each collection site and the number of maternal trees varied per site; thus, the effect of maternal tree on seedling response was not studied. All acorns from each population (species and provenance) were pooled together. Cups (woody involucre) of the acorns were removed, and undamaged acorns (e.g. those without insect damage) were placed in plastic bags containing peat moss. Acorns were cold-stratified at $41 \mathrm{C}$ for 90 days and then immersed in water for $24 \mathrm{~h}$. Acorns that floated were discarded; remaining acorns were placed in flats of moist vermiculite-based potting soil for germination on 1 January 2009. After separation from the pericarp, single acorns $(n=414)$ were weighed individually before sowing. After germination (emergence and development of the cotyledons), randomly chosen acorns $(n=280)$ were weighed and transplanted at 3-cm depth within a growth tube.

\section{Soils and growth tubes}

Approximately $600 \mathrm{~L}$ of ultramafic and mafic soils were collected in the Maryland piedmont from the upper $15 \mathrm{~cm}$ of the soil profile (grasslands for ultramafic soils and beneath a closed canopy for mafic soils). Mafic soils are of the Neshaminy series, forming very deep (>80 in) fertile farmland. Ultramafic soils are of the Chrome series, which are well drained, shallow (<30 in) and relatively infertile for crops. Soils were extensively homogenised, air-dried and sieved through a $2.0-\mathrm{mm}$ screen to remove large debris. A subset of the homogenised soils was collected for analysis. Soil $\mathrm{pH}$ was measured with a glass electrode in a soil-water slurry of $20 \mathrm{~g}$ soil in $20 \mathrm{~mL}$ of water. Samples were also evaluated for moisture retention (5-point scale), particle-size distribution, total acid-extractable metal analysis by microwave assisted $\mathrm{HNO}_{3}$ acid digestion using inductively coupled plasma-atomic emission spectroscopy (ICP-AES), combustion analysis of total carbon (C) and nitrogen $(\mathrm{N}), \mathrm{NH}_{4} \mathrm{Cl}$-extractable bases aluminium (Al), $\mathrm{Ca}$, $\mathrm{Mg}$, potassium $(\mathrm{K})$, sodium $(\mathrm{Na})$ analysis by ICP-AES and cation exchange capacity (CEC). Analyses were performed at the Cornell Nutrient Analysis Laboratory Ithaca, New York.

Experiments were conducted for one growth season with seedlings in cylindrical growth chambers (5-cm-diameter, Blue- $X^{\circledR}$, Enterprises, Inc., Sacramento, CA, USA). The respective soils were placed into the grow tubes utilising the following three experimental soil depths: $15 \mathrm{~cm}, 30 \mathrm{~cm}$ and $60 \mathrm{~cm}$, with four replicates for each of the seed types amounting to 280 growth tubes. Forty of these replicates were taken for early harvest. Additional replicates were limited by seed supply and available space. The bottom of each tube contained respective parent regolith down to $3-\mathrm{cm}$ depth, so as to facilitate drainage, and a pot supported each tube. Grow tubes were watered to saturation just before seedling placement.

\section{Greenhouse conditions and measurements}

A minimum12-h photoperiod was maintained with a combination of indoor and natural lighting. Natural lighting was supplemented with cool-beam, full-spectrum lamps to increase the photoperiod during the early growing season and to offset shading owing to greenhouse restrictions. Light conditions for the growing area were characterised by measuring photosynthetic photon flux rates over the 400-700-nm wavebands. Light conditions were uniform across the experimental area, with only minimal light obstruction from greenhouse support structures. Environmental conditions in the greenhouse varied according to daily weather, ranging as follows: photon flux at maximum chamber height of $60 \mathrm{~cm}, 230-1700 \mu \mathrm{mol} \mathrm{m}^{-2} \mathrm{~s}^{-1}$, day temperature $1840 \mathrm{C}$; and relative humidity $40-70 \%$ day and night. Grow tubes were watered at $200 \mathrm{~mL}^{\text {week }}{ }^{-1}$. Soil moisture was monitored using a ThetaProbe ${ }^{\circledR}$ (Dynamax, Inc., Houston, TX, USA) soil moisture sensor. At harvest, the oven dry mass (60 C for at least $48 \mathrm{~h}$ ) of roots, stems and leaves was determined, as well as the maximum rooting depth in the deeper tubes. The harvest data from March (40 samples after 21 days) and November 2009 (231 surviving seedlings) were used to calculate relative growth rate (RGR) and biomass allocation (root : shoot) values. RGR was calculated using the classical approach of Hunt (1990) where RGR is calculated from samples of individuals from the same cohort at two points in time (Evans 1972). A RGR was calculated for each seedling, using the following equation from Hunt (1990):

$$
r=\frac{\ln \left(\overline{w_{2}} \ln \overline{w_{1}}\right)}{t_{2}},
$$

where $w_{1}$ and $w_{2}$ are the plant dry mass across the harvest interval $\left(t_{2}-t_{1}\right)$.

Monthly parameters included volumetric soil moisture, germination, survival, growth (height, number of leaves, leaf length and width) humidity, photon flux, temperature and stomatal conductance. Stomatal conductance (in mmol $\mathrm{H}_{2} \mathrm{O}$ $\mathrm{m}^{-2} \mathrm{~s}^{-1}$ ) was measured on four occasions (30 May 2009, 20 June 2009, 20 July 2009 and 19 August 2009) with a steadystate diffusion leaf porometer (SC-1 Leaf porometer, Decagon Devices, Pullman, WA, USA). Stomatal conductance $\left(g_{\mathrm{s}}\right)$ measurements were taken from the abaxial surfaces of fully expanded upper leaves.

\section{Growth rates and plant tissue elemental analysis}

For elemental analysis, leaves from the uppermost recently matured leaves were harvested during the growing season (23 July, 1 per seedling) and at the conclusion of the experiment (7-9 November). Quercus marilandica and Q. stellata leaf tissue masses were sufficient for seed-provenance and soiltype treatments to be analysed separately. Quercus montana, Q. alba and Q. michauxii had insufficient leaf sample mass for elemental analysis from some treatments and, thus, leaves of these species were grouped (mixed) by soil type. Leaf tissue was homogenised in an agate ball mill and then analysed via combustion for total $\mathrm{C}$ and $\mathrm{N}$ and by ICP for major elements as well as arsenic (As), barium (Ba), beryllium $(\mathrm{Be})$, cadmium (Cd), $\mathrm{Co}, \mathrm{Cr}$, lithium (Li), Ni, lead ( $\mathrm{Pb}$ ), antimony ( $\mathrm{Sb}$ ), selenium $(\mathrm{Se})$, silicon $(\mathrm{Si})$, strontium $(\mathrm{Sr})$, thallium $(\mathrm{Tl})$, vanadium $(\mathrm{V})$. Analysis was performed by Ohio State University STAR Laboratory, Wooster, OH, USA, using nitric acid microwave digestion.

Treatments were maintained through November 2009. On harvest, first, plant heights were measured, then the entire shoot 
was cut off at soil level and separated into stems and leaves and roots. To extract roots from tubes, tubes were turned on their sides inside of a soil-washing container with 1-cm screen, the outermost liner was carefully removed and then the inner liner was peeled away from the soil and the depth of the root system (maximal rooting depth) was determined. This was measured only in the $60-\mathrm{cm}$-depth tubes as roots in the other treatments all extended to the maximum depth. All tissues and roots were dried separately at $60 \mathrm{C}$ for 7 days and massed. Specific root lengths (SRL) were calculated by dividing total root length $(\mathrm{m})$ by root biomass $(\mathrm{g})$ and root : shoot ratios were simply the dry weight for roots divided by dry weight of the aboveground part.

Because mycorrhizal root associations as well as other microbes are often important symbionts for nutrient uptake and plant performance, a bioassay was conducted at the conclusion of the experiment. A subset of soil samples was composited by soil type and assayed for active and total fungal and bacterial biomass, protozoa or nematode biomass and mycorrhizal colonisation. Sample combinations were randomised and watering was controlled to avoid mixing of microbial communities in the greenhouse. Analyses were performed by Soilfood Web Laboratory Corvallis, OR, USA. Active bacteria and fungi were counted by the fluorescein diacetate staining (FDA) method (Ingham and Klein 1982). Total bacterial numbers and the length of fungal hyphae were determined by phase-contrast microscopy and converted to micrograms of biomass per gram of dry soil.

\section{Statistical analysis}

The experiment was implemented and analysed as a completely randomised factorial design, using five species with two soil types, two provenances and three soil depths. For growth analyses, only seedlings surviving for the entire experimental period were included. Relationships between seed mass and growth parameters were analysed by regression analysis, and the curve equation and the value of $R^{2}$ were used to determine the correlation strength. Principal component analysis (PCA) on transformed data was used to evaluate seedling leaf elemental associations with the environmental factors (harvest date, species, provenance and soil type). Differences between soil types and foliar metal content were evaluated using Student's $t$-tests. Foliar elemental transfer efficiencies were evaluated with separate ANOVAs for each element, using harvest date, provenance and soil type as factors. Factorial ANOVAs were performed to test for differential responses and interactive effects between the response variables tissue nutrient/elemental concentrations, carbon allocation responses (stem height, biomass, RGR and leaf number) and the experimental factors soil type, provenance, species and soil depth. Repeated-measures ANOVA was used for stomatal-conductance responses, and using the corresponding moisture data for four census periods as a covariate. ANOVAs were followed by Tukey's (chosen because of an uneven number of replicates) multiple pairwise comparison to determine which species treatments had different biomass or growth-rate responses. To meet the assumptions of PCA or ANOVA, response-variable data were log-transformed as follows: natural $\log$ for foliar chemistry; $\log _{10}$ for stem height, biomass, root: shoot; and $\log _{10}+1$ for RGR. To analyse rooting-depth data, only the deep treatment was used, because plant roots typically grew to the full length in the more shallow treatments. Correlations were evaluated with the nonparametric Spearman rank correlation analysis because of deviation from normality and lack of any linear relationship of the leaf elemental data to other parameters. A significance level of $\alpha=0.05$ was used for the statistical tests, and a $P$-value of $<0.05$ indicated a significant difference. All errors are reported as standard error. All analyses were performed in R v.3.0.1 R (R Core Team 2013).

\section{Results}

Soils from the two provenances were loams (ultramafic), with 36-38\% sand, and silty-loams (mafic), with 18-20\% sand. Soil-water retention $(0.10,0.33,1.00,3.00$ and 15.00 bars) was similar, except the mafic material had a higher matric potential $(22.38 \%$ versus $20.03 \%)$ at 3 bars.

Soil $\mathrm{pH}$ values were effectively biologically neutral, with $6.400 .02(n=10)$ and $6.850 .04(n=10)$ for mafic and serpentine soils, respectively. Soil organic $\mathrm{C}$, total $\mathrm{N}$ and $\mathrm{CEC}$ were similar (Table 1). Notable differences either in the extractable bases or the total metal concentrations included a nearly a four-fold difference in $\mathrm{Mg}$ (elevated in ultramafic soils), a four-fold difference in $\mathrm{Ca}$ (elevated in mafic soils), a 8-10-fold difference in $\mathrm{Cr}$, Co and $\mathrm{Ni}$ (elevated in ultramafic soils), a twofold difference in $\mathrm{Al}$ (elevated in mafic soils) and a two-fold difference in iron (Fe) content (elevated in ultramafic soils). The parent material discrimination metric $(\mathrm{Ca}+\mathrm{Mg}): \mathrm{Mg}$ espoused by Shaw et al. (2001) yielded marked differences of 0.23 for ultramafic soils and 5.63 for mafic soils, using exchangeable base data and a factor of 10 difference using total metals $(0.07$ for ultramafic and 0.61 for mafic soils). Thus, these soils have similar nutritional content $(\mathrm{C}, \mathrm{N}, \mathrm{Na}$, phoshorus $(\mathrm{P}), \mathrm{K})$ but with an imbalance in the $\mathrm{Ca}: \mathrm{Mg}$ ratio and water-holding capacity.

The structure of the soil microbial community was similar between the two soils, with both being dominated by bacterial biomass and having a fungi : bacteria ratio less than unity (Table 2). ANOVA results suggested a significant $(P<0.05)$ relationship between soil moisture content and stomatal conductance with soil depth during all sampling periods.

\section{Differences in seed mass}

Initial fresh seed mass significantly differed among the Quercus species (ANOVA $F_{9,749}=873.7, P<0.001$; Table 3 ). Only three species had acorns with a statistically significant different in seed mass between soil types (Q. marilandica, Q. montana and Q. alba). Quercus marilandica and $Q$. stellata had the lowest masses of $\sim 1.1-1.6 \mathrm{~g}$, with no significant difference for the pair on the basis of provenance. Quercus montana and Q. alba had larger seeds ( $\sim \mathrm{g}$ fresh mass), with both species showing significant differences in mass on the basis of provenance (smaller seeds on serpentine substrate). The largest seeds belonged to $Q$. michauxii at $\sim 10 \mathrm{~g}$, with larger seeds occurring in ultramafic soils. The relationship between seed mass and RGR $\left(r_{\mathrm{s}}=0.223, P=0.007\right)$ and stem height $\left(r_{\mathrm{s}}=0.493, P \quad 0.001\right)$ for all data points was considered using Spearman's rank correlation, which suggested a weak positive relationship between initial acorn mass and ultimate seedling performance. 


\section{Foliar elemental content}

Concentrations of extractable elements in leaf tissue varied considerably and significantly (ANOVA, $P<0.05$ ) between the July and August harvest dates. Mean concentrations of heavy metals in leaf were significantly (one-way ANOVA,

Table 1. Total and extractable metal concentrations, $\mathrm{pH}$ and chemical soil characteristics for the two experimental soils

\begin{tabular}{|c|c|c|}
\hline Parameter & $\begin{array}{l}\text { Serpentine } \\
\text { soils }\end{array}$ & $\begin{array}{l}\text { Mafic } \\
\text { soils }\end{array}$ \\
\hline \multicolumn{3}{|l|}{ Soil characteristic } \\
\hline $\mathrm{N}(\%)$ & 0.35 & 0.32 \\
\hline $\mathrm{C}(\%)$ & 3.91 & 3.62 \\
\hline $\mathrm{pH}$ & 6.85 & 6.40 \\
\hline $\mathrm{NO}_{3}+\mathrm{NO}_{2}\left(\mathrm{mg} \mathrm{kg}^{-1}\right)$ & 49.02 & 44.76 \\
\hline $\mathrm{NH}_{4}-\mathrm{N}\left(\mathrm{mg} \mathrm{kg}^{-1}\right)$ & 6.58 & 10.87 \\
\hline Cation exchange capacity $\left(\mathrm{cmol} \mathrm{kg}^{-1}\right)$ & 28.33 & 21.80 \\
\hline \multicolumn{3}{|c|}{ Concentration of an extractable base $\left(\mathrm{mg} \mathrm{kg}^{-1}\right)$} \\
\hline Sodium & 46.47 & 13.15 \\
\hline Magnesium & 1087.11 & 243.99 \\
\hline Aluminium & 3.98 & 8.34 \\
\hline Calcium & 241.08 & 1310.10 \\
\hline Manganese & 3.43 & 15.08 \\
\hline Iron & 7.39 & 1.74 \\
\hline Zinc & 5.81 & 8.21 \\
\hline \multicolumn{3}{|l|}{ Total metal concentration $\left(\mathrm{mg} \mathrm{kg}^{-1}\right)$} \\
\hline Sodium & 64.18 & 57.04 \\
\hline Magnesium & 15970.00 & 2619.00 \\
\hline Aluminium & 7057.00 & 13830.00 \\
\hline Phosphorus & 614.10 & 584.50 \\
\hline Potassium & 480.90 & 281.90 \\
\hline Calcium & 561.20 & 1314.00 \\
\hline Chromium & 369.80 & 31.48 \\
\hline Manganese & 1332.00 & 942.70 \\
\hline Iron & 40720.00 & 18400.00 \\
\hline Cobalt & 104.90 & 13.36 \\
\hline Nickel & 1155.00 & 18.04 \\
\hline
\end{tabular}

$P \quad 0.05)$ different for all but $\mathrm{Cr}$ and $\mathrm{Fe}$ on the basis of soil treatments (Table 4). The variation in foliar content was similar for $\mathrm{C}(44.3-49.1 \%)$ across sampling dates, whereas for $\mathrm{N}$ $(0.6-2.6 \%)$, there was a significant $\left(\begin{array}{ll}P & 0.01\end{array}\right)$ difference, with a contraction in values during the November sampling. ANOVA using soil type as a factor and leaf trace-element concentration as the response variables showed significant $(P<0.05)$ differences for N, sulfur (S), P, Ca, Mg, manganese (Mn), Ni and zinc ( $\mathrm{Zn}$ ), with $\mathrm{K}$ falling just outside the threshold criteria $(P=0.06)$. These data were analysed using a principal-component analysis to reduce dimensionality and increase overall pattern recognition (Fig. 1). To identify the effect from the experimental factors on the extractable leaf elements, the correlations of the extracted vectors of each PCA axis with harvest date, soil type, provenance and species were assessed by regression analysis (Table 5). The first PCA axis explained $39 \%$ of the total variance and was significantly correlated with soil type and harvest date. The second axis was correlated with harvest date, whereas provenance and species were significantly correlated with the third principal axis. Leaf P, N, K and S loaded mainly on this first axis, leaf $\mathrm{Ca}$ and $\mathrm{Mn}$ mainly loaded on the second axis, which explained $27 \%$ of the data, and leaf $\mathrm{Mg}$ and $\mathrm{Ni}$ loaded on the third axis, explaining $16 \%$ of the data. The data are consistent with basic nutrients being sensitive to leaf harvest date (growth and abscission), with Mg content aligning with particular species or provenance.

To test for the strength of association of leaf element concentration between the two soil treatments, Spearman's rank correlation was conducted, showing that foliar concentration was strongly correlated between the two soil treatments $\left(r_{\mathrm{s}}=0.97, P \quad 0.001, n=29\right)$. Notable differences included higher leaf $\mathrm{Ca}$ in seedlings grown in mafic soils and higher $\mathrm{Mg}$ and $\mathrm{Ni}$ in typical serpentine soils, whereas $\mathrm{P}, \mathrm{K}$ and $\mathrm{Fe}$ were more elevated in the ultramafic soils, perhaps owing to allochthonous input.

As is typical of ultramafic soils, leaf concentration was diagnostic of ultramafic soils for several elements $(\mathrm{Ca}, \mathrm{Mg}, \mathrm{Ni}$ and $\mathrm{Cr}$ ). These elements are displayed in Fig. 2, which highlights

Table 2. Ratios and estimated biomass of total populations of different functional groups from composite soil samples Units are $\mu \mathrm{g} \mathrm{g}^{-1}$ biomass from actual count data

\begin{tabular}{lcccccc}
\hline Soil parent & $\begin{array}{c}\text { Active bacteria } \\
\left(\mu \mathrm{g} \mathrm{g}^{-1}\right)\end{array}$ & $\begin{array}{c}\text { Total bacteria } \\
\left(\mu \mathrm{g} \mathrm{g}^{-1}\right)\end{array}$ & $\begin{array}{c}\text { Active } \\
\text { fungi }\left(\mu \mathrm{g} \mathrm{g}^{-1}\right)\end{array}$ & $\begin{array}{c}\text { Total fungi } \\
\left(\mu \mathrm{g} \mathrm{g}^{-1}\right)\end{array}$ & $\begin{array}{c}\text { Mycorrhizal } \\
\left.\text { colonisation }(\mu \mathrm{g} \mathrm{g})^{-1}\right)\end{array}$ & $\begin{array}{c}\text { Active fungi to } \\
\text { active bacteria ratio }\end{array}$ \\
\hline Ultramafic serpentine & 59.70 & 1179.00 & 30.70 & 659 & Not detected & 0.51 \\
Mafic gabbro & 48.80 & 1347.00 & 16.90 & 495 & Not detected & 0.35 \\
\hline
\end{tabular}

Table 3. Statistical parameters for acorn $(n=759)$ mass of Quercus species

$P$-values (from ANOVA) represent comparisons of seed mass by species across their resident soil types. The multiple comparisons of means followed the Tukey's method. IQR, interquartile range

\begin{tabular}{lrrrrrrrr}
\hline Seed species & $n$ & \multicolumn{2}{c}{ Seed fresh smass (serpentine provenance) } & $n$ & \multicolumn{2}{c}{ Seed fresh mass (mafic provenance) } \\
& & Mean \pm s.e. & IQR & Germination (\%) & & Mean \pm s.e. & IQR & Germination (\%) \\
\hline Q. marilandica & 123 & $1.18 \pm 0.19$ & 0.27 & 94.3 & 64 & $1.22 \pm 0.05$ & 0.59 & 95.3 \\
Q. stellata & 70 & $1.14 \pm 0.03$ & 0.36 & 91.4 & 68 & $1.64 \pm 0.03$ & 0.34 & 94.1 \\
Q. michauxii & 58 & $10.39 \pm 0.20$ & 1.61 & 98.2 & 65 & $9.77 \pm 0.22$ & 2.32 & 93.8 \\
Q. montana & 63 & $4.21 \pm 0.16$ & 1.68 & 89.9 & 69 & $5.87 \pm 0.11$ & 1.25 & 85.7 \\
Q. alba & 100 & $3.98 \pm 0.08$ & 0.89 & 65.6 & 79 & $4.64 \pm 0.13$ & 1.97 & 83 \\
\hline
\end{tabular}


Table 4. Foliar elemental concentration (in $\mu \mathrm{g} \mathrm{g}^{-1}$ for metals; in \% for carbon (C) and nitrogen (N)) in oak leaves

$Q s, Q$. stellata; $Q$. ma, Q. marilandica; $Q$. mo, Q. montana; $Q a, Q . a l b a$; and Qmi, Q. michauxii; $\mathrm{M}$, mafic soil chemistry; $\mathrm{G}$, gabbro home site; U, ultramafic soil chemistry; S, serpentine home site; Mix, combined samples from both provenance locations; P, phosphorus; S, sulfur; K, potassium; Ca, calcium; $\mathrm{Mg}$, magnesium; Al, aluminium; $\mathrm{Cu}$, copper; Fe, iron; Mn, manganese; $\mathrm{Zn}$, zinc; $\mathrm{Cr}$, chromium; Ni, nickel

\begin{tabular}{|c|c|c|c|c|c|c|c|c|c|c|c|c|c|c|c|c|}
\hline $\begin{array}{l}\text { Harvest } \\
\text { date }\end{array}$ & $\begin{array}{c}\text { Soil parent } \\
\text { or provenance }\end{array}$ & Species & $\mathrm{N}$ & $\mathrm{C}$ & $\mathrm{P}$ & $\mathrm{S}$ & $\mathrm{K}$ & $\mathrm{Ca}$ & $\mathrm{Mg}$ & $\mathrm{Al}$ & $\mathrm{Cu}$ & $\mathrm{Fe}$ & $\mathrm{Mn}$ & $\mathrm{Zn}$ & $\mathrm{Cr}$ & $\mathrm{Ni}$ \\
\hline July & $\mathrm{M} / \mathrm{G}$ & $Q s$ & 1.9 & 47.2 & 1455.7 & 1081.7 & 11356.7 & 4075.8 & 2003.3 & 31.8 & 10.6 & 66.1 & 456.4 & 22.0 & 0.9 & 6.7 \\
\hline July & $\mathrm{M} / \mathrm{G}$ & Qma & 1.8 & 48.4 & 532.8 & 951.0 & & 3589.1 & 2256.9 & & & & & 14.4 & 0.9 & 8.0 \\
\hline July & $\mathrm{M} / \mathrm{S}$ & $Q s$ & 2.0 & 47.2 & 1255.5 & 1200.6 & 8453.0 & 5134.2 & 2149.0 & 27.6 & 5.8 & 92.9 & 519.8 & 23.6 & 1.1 & 5.1 \\
\hline July & $\mathrm{M} / \mathrm{S}$ & Qma & 2.5 & 46.8 & 986.8 & 1682.6 & 6269.2 & 4272.8 & 2150.8 & 32.9 & 4.2 & 85.0 & 957.4 & 34.0 & 1.6 & 1.9 \\
\hline July & M/Mix & Qmo & 2.4 & 45.1 & 961.5 & 1770.2 & 5075.1 & 16696.6 & 5142.7 & 27.5 & 5.1 & 98.0 & 1496.2 & 24.1 & 2.0 & 2.4 \\
\hline July & M/Mix & $Q a$ & 2.2 & 46.1 & 1111.8 & 1669.8 & 8775.1 & 10255.9 & 3568.0 & 11.1 & 4.9 & 58.2 & 1412.5 & 20.3 & 1.7 & 4.3 \\
\hline July & M/Mix & $Q m i$ & 2.6 & 46.0 & 712.7 & 1684.9 & 4588.7 & 13500.3 & 3293.7 & 37.1 & 5.8 & 102.7 & 1903.3 & 18.9 & 2.3 & 1.5 \\
\hline Nov. & $\mathrm{M} / \mathrm{G}$ & $Q s$ & 0.8 & 46.7 & 387 & 866.4 & 1067.9 & 8210.5 & 2398.2 & & 3.6 & & 1037.7 & 18.5 & 1.4 & 11.2 \\
\hline Nov. & $\mathrm{M} / \mathrm{G}$ & $Q m a$ & 0.8 & 48.2 & 213.7 & 803.2 & 818 & 7724.6 & 5817.0 & 18 & 2.4 & 49.5 & 454.9 & 26.6 & 1.1 & 16.4 \\
\hline Nov. & $\mathrm{M} / \mathrm{S}$ & $Q s$ & 0.9 & 46.5 & 356.6 & 939.2 & 2153.2 & 8312.4 & 2140.9 & 76.1 & 4.5 & 163.3 & 1858.9 & 30.6 & 3.2 & 7.5 \\
\hline Nov. & $\mathrm{M} / \mathrm{S}$ & Qma & 1.4 & 47.0 & 752.7 & 1284.4 & 4790.6 & 9362.2 & 1919.4 & 19.3 & 3.3 & 81.0 & 2271.2 & 49.5 & 2.3 & 1.5 \\
\hline Nov. & M/Mix & Qmo & 1.6 & 44.3 & 569.9 & 1639.8 & 1563.9 & 21836.6 & 6357.4 & 93.6 & 4.0 & 203.3 & 3323.2 & 21.7 & 4.2 & 2.9 \\
\hline Nov. & M/Mix & $Q a$ & 0.9 & 46.5 & 562.7 & 1004.6 & 2498.9 & 10507.5 & 2127.7 & 42.9 & 3.2 & 65.0 & 2608.0 & 17.5 & 2.9 & 4.7 \\
\hline Nov. & M/Mix & $Q m i$ & 2.0 & 45.9 & 867.0 & 1624.1 & 2633.6 & 15711.6 & 3688.0 & & 3.7 & 127.1 & 3853.4 & 27.3 & 3.9 & 2.1 \\
\hline July & & $Q s$ & 2.1 & 48.1 & 656.5 & 1134.4 & 5100 & & 3448.2 & & 5.3 & & 326.9 & 14.0 & 0.7 & 15.4 \\
\hline July & $\mathrm{U} / \mathrm{G}$ & $Q m a$ & 1.8 & 48.4 & 584.0 & 1002.4 & 3889.6 & 8595.1 & 4622.1 & 30.6 & 4.5 & 70.5 & 137.4 & 16.0 & 0.8 & 8.9 \\
\hline July & $\mathrm{U} / \mathrm{S}$ & $Q s$ & 2.0 & 47.9 & 550.6 & 1044.2 & 4049.5 & 4460.2 & 3999.2 & 24.6 & 3.7 & 63.7 & 110.6 & 13.3 & 0.7 & 7.8 \\
\hline July & $\mathrm{U} / \mathrm{S}$ & $Q m a$ & 1.9 & 47.9 & 550.5 & 1062.3 & 3303.9 & 3707.2 & 4843.9 & 21. & 3.1 & 145.1 & 142.4 & 13.7 & 0.9 & 11.1 \\
\hline July & U/Mix & Qmo & 2.2 & 46.5 & 1013.0 & 1305.0 & 4501.3 & 6407.4 & 6460.3 & 45.1 & 3.8 & 118.0 & 379.2 & 14.7 & 1.4 & 13.1 \\
\hline July & U/Mix & $Q a$ & 2.0 & 46.9 & 987.3 & 1208.0 & 4570.6 & 5782.2 & 4195.8 & 21.4 & 4.8 & 95.7 & 719.7 & 13.3 & 1.4 & 18.6 \\
\hline July & U/Mix & $Q m i$ & 2.3 & 45.4 & 752.7 & 1363.1 & & 7701.5 & 11387.9 & 32. & 2.4 & 95.9 & 156.5 & 16.1 & 1.1 & 8.8 \\
\hline Nov. & $\mathrm{U} / \mathrm{G}$ & $Q s$ & 0.7 & 46.7 & 263.9 & 795.7 & 1158.2 & 6990.0 & 4844.2 & 21.5 & 3.3 & 67.4 & 1044.4 & 17.6 & 1.4 & 12.0 \\
\hline Nov. & $\mathrm{U} / \mathrm{G}$ & Qma & 0.7 & 49.1 & 148.8 & 872.1 & 780.2 & 8178.4 & 5685.5 & 23.6 & 3.0 & 71.6 & 664.6 & 18.7 & 1.6 & 6.7 \\
\hline Nov. & $\mathrm{U} / \mathrm{S}$ & $Q s$ & 1.0 & 47.3 & 193.4 & 870.5 & 1000.8 & 6176.5 & 3387.6 & 32.1 & 3.8 & 69.6 & 1055.2 & 17.0 & 2.3 & 38.9 \\
\hline Nov. & $\mathrm{U} / \mathrm{S}$ & Qma & 1.0 & 48.4 & 215.8 & 991.8 & 1203.2 & 6734.6 & 3801.1 & 30.4 & 3.7 & 85.6 & 2706.7 & 24.3 & 3.6 & 26.2 \\
\hline Nov. & U/Mix & Qmo & 0.1 & 47.0 & & 1013.2 & & & & 79.8 & 3.0 & 186.1 & 2040.1 & 12.1 & 3.5 & 26.4 \\
\hline Nov. & U/Mix & $Q a$ & 0.6 & 46.3 & 353.2 & 948.8 & 1880.5 & 7583.5 & 5820.1 & 24.7 & 2.9 & 58.9 & 828.4 & 12.4 & 1.7 & 17.9 \\
\hline \multirow[t]{3}{*}{ Nov. } & U/Mix & $Q m i$ & 0.7 & 46.3 & 575.7 & 1079.2 & 2106.0 & 6877.1 & 9499.3 & 52.0 & 1.9 & 121.0 & 138.8 & 13.4 & 1.4 & 8.9 \\
\hline & Mean & Ultramafic & 1.5 & 47.3 & 513.5 & 1049.3 & 2717.4 & 6750.7 & 5568.5 & 32.7 & 3.5 & 93.2 & 746.5 & 15.5 & 1.6 & 15.8 \\
\hline & Mean & Mafic & 1.3 & 46.6 & 766.2 & 1300.2 & 4567.9 & 9942.1 & 3215.2 & 38.1 & 4.7 & 95.4 & 1588.7 & 24.9 & 2.1 & 5.4 \\
\hline
\end{tabular}

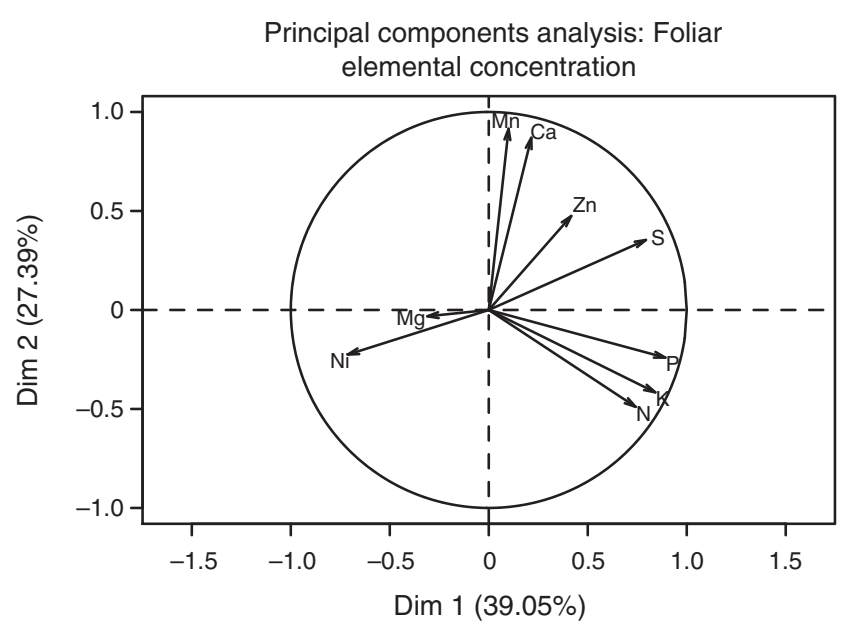

Fig. 1. Projection of the leaf elemental concentrations for all independent samples $(n=28)$ on the two first axes of the principal component analysis (PCA).

the time factor or harvest date for $Q$. stellata and $Q$. marilandica. These two species are detailed here, because they are the primary serpentine savanna woody species and they have the most complete foliar element dataset. Broadly speaking, across the entire growing season, the mean concentration of extractable $\mathrm{Ca}$ was lowest in $Q$. marilandica $\left(5896 \mu \mathrm{g} \mathrm{g}^{-1}\right)$ and $Q$. stellata $\left(5622 \mu \mathrm{g} \mathrm{g}^{-1}\right)$, whereas $Q$. michauxii $\left(10948 \mu \mathrm{g} \mathrm{g}^{-1}\right)$ and Q. montana $\left(13160 \mu \mathrm{g} \mathrm{g}^{-1}\right)$ exhibited a two-fold increase, with Q. alba $\left(8532 \mu \mathrm{g} \mathrm{g}^{-1}\right)$ being intermediate, even though $\mathrm{Mg}$ concentrations were similar in the resident seedlings, decreasing slightly in the non-resident treatments (Table 4). Ni and Cr uptake was similar for the two Quercus species, whereas tissue concentrations of $\mathrm{Cr}$ were lower and those of Ni doubled for $Q$. montana and there was a five-fold increase in $Q$. stellata just before abscission fall harvest for the resident serpentine treatment. A two-way ANOVA was used to examine the effect of metal concentration on the basis of soil type and seed origin for the serpentine signature elements $\mathrm{Ca}, \mathrm{Mg}, \mathrm{Cr}$, $\mathrm{Ni}$ as well as the $\mathrm{Ca}: \mathrm{Mg}$ ratio. There was a significant interaction between the effects of seed provenance and soil type for $\mathrm{Ca}: \mathrm{Mg}(F$ $(2,22)=3.426, P=0.049), \mathrm{Ca}(F(2,22)=5.248, P=0.014)$ and Ni $(F(2,22)=3.510, P=0.047)$. Simple main effect analysis showed that $\mathrm{Ca}: \mathrm{Mg}(P$ 0.0001), Ca $(P=0.0008), \mathrm{Mg}$ $(P=0.001)$ and $\mathrm{Ni}(P=0.0004)$ were significantly related to soil type, whereas there were no differences in $\mathrm{Cr}$ concentration among the soil types $(P=0.161)$, although 
Table 5. The factor loadings of nine leaf elements on the first three principal component analysis (PCA) axes, and correlation coefficients between each PCA axis and each of three environmental factors Asterisks mark the significant $(P<0.05)$ correlations between the PCA axis and the environmental factors $(n=28)$

\begin{tabular}{lccc}
\hline Parameter & Component 1 & Component 2 & Component 3 \\
\hline Factor & & & \\
$\quad$ Nitrogen & 0.741 & -0.489 & 0.147 \\
Phosphorus & 0.892 & -0.241 & 0.078 \\
Potassium & 0.841 & -0.416 & -0.130 \\
Sulfur & 0.794 & 0.354 & 0.380 \\
Calcium & 0.215 & 0.869 & 0.340 \\
Magnesium & -0.310 & -0.032 & 0.865 \\
Manganese & 0.100 & 0.915 & -0.145 \\
Nickel & -0.712 & -0.225 & -0.082 \\
Zinc & 0.417 & 0.475 & -0.528 \\
Total variation explained (\%) & 39 & 27 & 16 \\
Correlation $(r)$ with environmental factors & & \\
Harvest date & $0.404^{*}$ & $0.413 *$ & 0.048 \\
Soil type & $0.336^{*}$ & 0.184 & 0.118 \\
Provenance & 0.059 & 0.136 & $0.518^{*}$ \\
Species & 0.034 & 0.183 & $0.602^{*}$ \\
\hline
\end{tabular}

differences were seen by provenance $(P=0.030)$. The foliar concentrations of $\mathrm{Ca}(P=0.0003)$ and $\mathrm{Mg}(P=0.007)$ also differed according to the seed origin, whereas that of $\mathrm{Ni}$ did not $(P=0.585)$.

Ratios between the total concentration of metal in seedling soil and that in leaves were used to estimate transfer or leafconcentration factors. The soil-leaf transfer factors were correlated between the two soil treatments $(r=0.97$, $P \quad 0.001)$. For major plant nutrients ( $\mathrm{P}, \mathrm{N}, \mathrm{K}$ and $\mathrm{S})$, species typically have greater than unity transfer efficiencies (TEs). The two highest TEs were for $\mathrm{Ca}$ (10.63 0.88 for ultramafic; 7.570 .56 for mafic) and $\mathrm{N}$ (4.43 0.44 for ultramafic; 5.310 .54 for mafic), whereas the other major element of interest, $\mathrm{Mg}$, indicated 0.350 .39 for ultramafic and 1.230 .16 for mafic soils.

The multi-way ANOVA (Table 6) clearly showed the dominance of the harvest-time effect in the TEs of major plant nutrients $(\mathrm{N}, \mathrm{P}, \mathrm{K}, \mathrm{S}, \mathrm{Ca})$ as well as in those of $\mathrm{Li}, \mathrm{Ba}, \mathrm{Mn}$ and $\mathrm{Cr}$. The seed-provenance effect was significant for a variety of trace elements and nutrients: $\mathrm{Li}, \mathrm{Na}, \mathrm{S}, \mathrm{Ca}, \mathrm{Mn}, \mathrm{Cr}, \mathrm{Ni}, \mathrm{Zn}, \mathrm{Sr}$ and $\mathrm{Ba}$. As expected, soil type was a significant factor for nearly all of the nutrients and trace elements (exceptions were $\mathrm{Na}, \mathrm{Al}$ and $\mathrm{Fe}$ ). Most of the interactions were not significant, with the exception of the seed-provenance and soil-type interaction for the elements $\mathrm{Li}, \mathrm{S}, \mathrm{Cr}, \mathrm{Mn}, \mathrm{Ni}, \mathrm{Zn}$ and $\mathrm{Ba}$.

\section{Seedling growth responses}

Seedling mortality was low (3.75\%), but telling. Eight of the nine plants that died were grown in ultramafic soil but had mafic provenance, and the remaining plant had ultramafic provenance and was grown in its home soil.

Significant differences in shoot (stem) height were evident for soil depth, type and species, although a variety of interactions were significant as well, clouding the interpretation (Table S1, available as Supplementary material for this paper). Interaction plots were generated for each pair of factors recording significant effects (Fig. 3). The plot of provenance versus soil type suggested (although ANOVA $P=0.18$ ) that seedlings whose acorns came from mafic soils tended to grow taller than those from ultramafic soils in mafic treatment; whereas seeds from mafic provenance grew less on the ultramafic treatment. Fig. $3 b$ supports the conclusion that seedlings in the deeper mafic soils experienced a greater increase in shoot height. Graphs of species and soil type (Fig. 3c) and soil depth (Fig. 3d) generally show that seedlings grew taller in deeper soils and mafic soils, with differential results depending on species. Differences in growth on the basis of soil depth may also be driven by $Q$. michauxii.

As above, interaction plots were generated for those ANOVA interaction effects that were significant (Fig. 4). Figure $4 a$ shows the RGR for soil type and soil depth, with mafic soil types outperforming their ultramafic counterparts at each soil depth. RGRs were high in the deeper soil treatments. Figure $4 b$ details species RGR and soil type, with $Q$. montana showing the smallest differential among the soil types and $Q$. michauxii showing the biggest disparity in RGR among soil types, with $Q$. alba being comparable. Seedlings grown in deeper soils tended to have a higher RGR, with $Q$. michauxii showing the largest increase compared with other species (Fig. 4c). Interactions between seed provenance and species were examined; however, the wide standard error bars and lack of statistical significance preclude any meaningful interpretation (Table S2, available as Supplementary material for this paper).

Root to shoot data were investigated using a factorial ANOVA, and normality tests indicated that the model met ANOVA assumptions. Similar to the above data, interaction plots were generated for the significant interactions (Fig. 5; Table S3, available as Supplementary material for this paper). The root: shoot plot (Fig. $5 a-c$ ) combined with seed provenance and soil type indicated that seedlings with seeds taken from ultramafic sites and grown in the same soils had a higher root: shoot ratio $(P<0.05)$, and that those from mafic sites grown in the mafic soils did not show the same type of growth plasticity. Plants in ultramafic soil, regardless of provenance, had a greater root: shoot ratio, whereas Fig. $5 d$ demonstrably shows that the root: shoot ratio of $Q$. marilandica as well as Q. stellata responded to the shallow soil treatment and both Q. marilandica and $Q$. stellata had higher root: shoot ratios than did the other species when all depths were averaged by soil type. Both $Q$. marilandica and $Q$. stellata had noticeably higher root: shoot ratios when resident seeds were grown in ultramafic soils.

For the three-way significant interactions, data were examined as subsets by species. Much of the data were inconclusive because of large standard error bars, but some information can be taken from Fig. 5. Root: shoot ratio varied by species and each species responded to treatments differently. An elevated root : shoot ratio was seen in serpentine soils for most species when grown in the shallow-depth treatment, other depths showed no significant differences or trends. $Q$. michauxii was the only species with a lower root: shoot ratio in serpentine soils, and this was the case for all depths. For some species, the soil type from which seeds were collected influenced root: shoot ratios and how the seedlings responded to the soil treatments. $Q$. marilandica and $Q$. stellata 

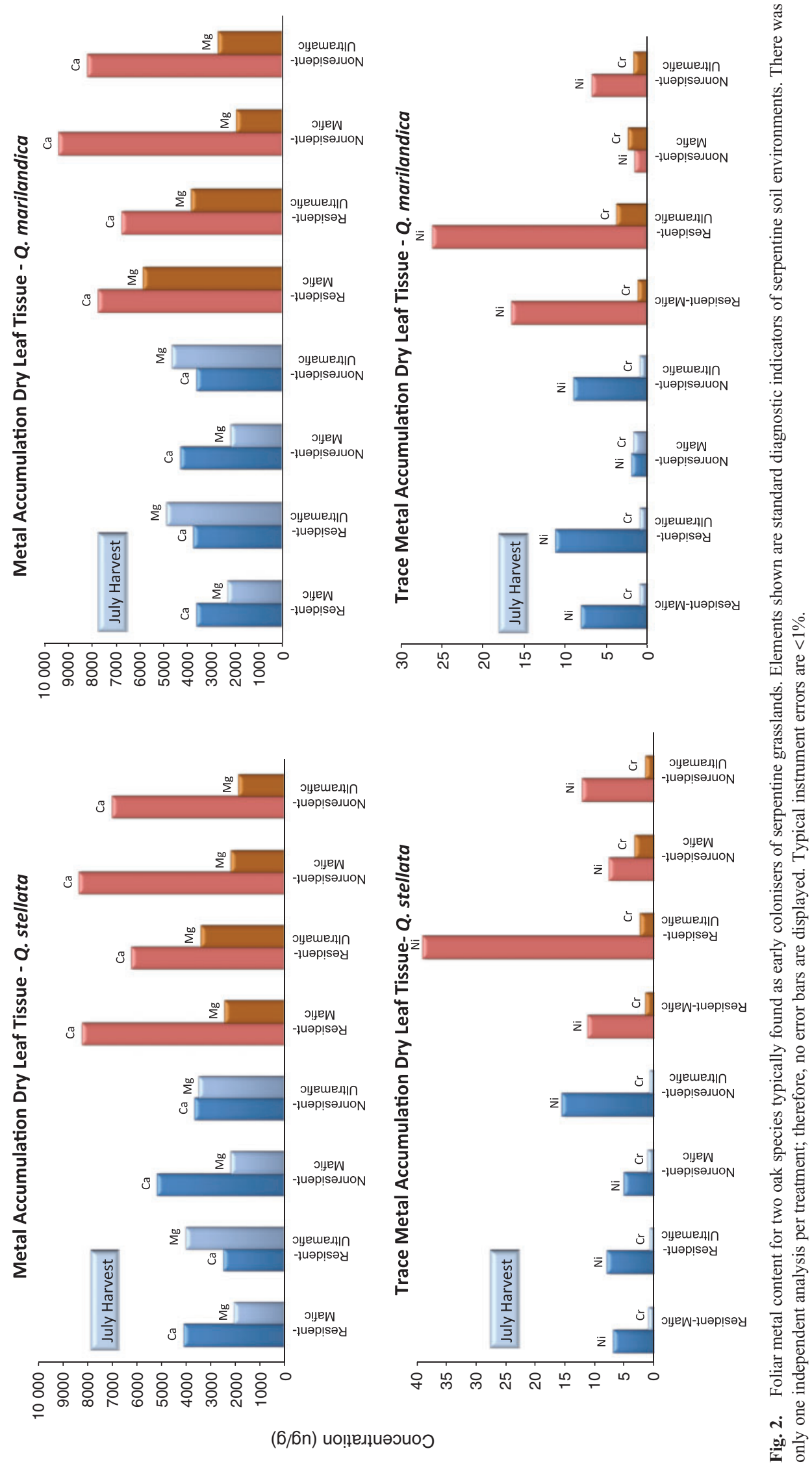
Table 6. ANOVA results for leaf-soil transfer efficiencies as a function of harvest date, provenance and soil type Data were calculated using extractable bases for sodium ( $\mathrm{Na})$, magnesium $(\mathrm{Mg})$, aluminium (Al), calcium (Ca), manganese (Mn), iron (Fe) and zinc ( $\mathrm{Zn})$. Total metal values were used for the remaining elements. Significant $(P<0.05)$ differences are in bold

\begin{tabular}{|c|c|c|c|c|c|c|c|c|c|c|c|c|c|c|c|c|}
\hline \multirow[t]{2}{*}{ Factor } & \multicolumn{16}{|c|}{ Element } \\
\hline & $\mathrm{Li}$ & B & $\mathrm{N}$ & $\mathrm{Na}$ & $\mathrm{Mg}$ & $\mathrm{Al}$ & $\mathrm{P}$ & $\mathrm{S}$ & K & $\mathrm{Ca}$ & $\mathrm{Cr}$ & $\mathrm{Mn}$ & $\mathrm{Fe}$ & $\mathrm{Ni}$ & $\mathrm{Zn}$ & $\mathrm{Ba}$ \\
\hline Harvest date & 0.005 & 0.438 & $<0.001$ & 0.011 & 0.508 & 0.071 & $<0.001$ & 0.005 & $<0.001$ & $<0.001$ & $<0.001$ & $<0.003$ & 0.242 & 0.077 & 0.061 & 0.010 \\
\hline Provenance & $<0.001$ & 0.065 & 0.058 & 0.109 & 0.047 & 0.085 & 0.160 & $<0.001$ & 0.812 & $<0.001$ & $<0.001$ & 0.304 & 0.162 & $<0.001$ & 0.005 & $<0.001$ \\
\hline Soil type & $<0.001$ & 0.071 & 0.052 & 0.032 & $<0.001$ & 0.008 & 0.004 & $<0.001$ & $<0.001$ & $<0.001$ & $<0.001$ & $<0.046$ & 0.001 & $<0.001$ & 0.135 & $<0.001$ \\
\hline Harvest date provenance & 0.152 & 0.664 & 0.011 & 0.229 & 0.444 & 0.189 & 0.681 & 0.910 & 0.501 & 0.017 & 0.075 & 0.334 & 0.656 & 0.182 & 0.076 & 0.301 \\
\hline Harvest date soil & 0.728 & 0.854 & 0.849 & 0.617 & 0.510 & 0.913 & 0.708 & 0.395 & 0.023 & 0.002 & $<0.001$ & 0.086 & 0.251 & 0.103 & 0.604 & 0.384 \\
\hline Provenance soil & 0.016 & 0.236 & 0.424 & 0.167 & 0.480 & 0.507 & 0.300 & 0.020 & 0.592 & 0.304 & $<0.001$ & 0.481 & 0.439 & $<0.001$ & 0.050 & 0.002 \\
\hline $\begin{array}{l}\text { Harvest date provenance } \\
\text { soil }\end{array}$ & 0.289 & 0.979 & 0.758 & 0.977 & 0.683 & 0.992 & 0.389 & 0.801 & 0.747 & 0.051 & 0.176 & 0.362 & 0.680 & 0.159 & 0.904 & 0.502 \\
\hline
\end{tabular}
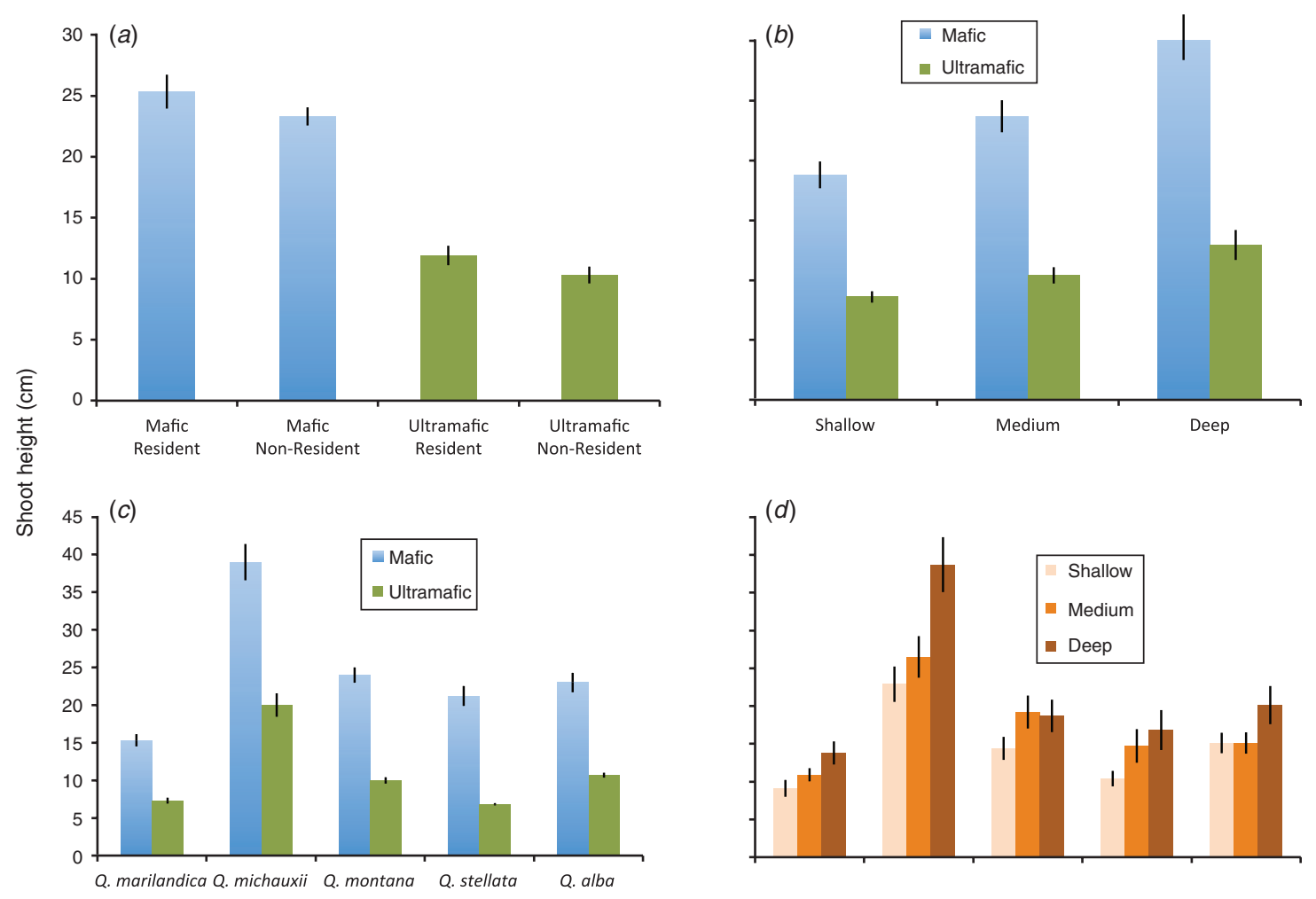

Fig. 3. Interaction plots for mean shoot height, for provenance and soil type, soil type and soil depth, soil type and species, and soil depth and species. Shallow, $15 \mathrm{~cm}$; medium, $30 \mathrm{~cm}$; and deep, $60 \mathrm{~cm}$. Interactions were all significant at $P \quad 0.05$. Error bars are s.e.

from serpentine soils had higher root: shoot ratios than did these same species from mafic soils. Additionally, seedlings from serpentine soils tended to have higher root: shoot ratios when grown in resident provenance soils. Data did not support this conclusion for seedlings from mafic soils.

Data for rooting depth are restricted to only the deeper $(60 \mathrm{~cm})$ growth tubes. Soil type and species main effects as well as their interaction effects were significant, with root depth being deeper in mafic soils for all five species (ANOVA, Table S4, available as Supplementary material for this paper). The provenance main effect had a $P$-value of 0.077 , suggesting a possible trend. Figure 6 displays box-plot data for root depth by species and soil type. Clearly, seedlings grown in mafic soils had deeper roots than their counterparts grown in ultramafic soils. The degree of difference between the soil types varied by species, with perhaps, the greatest relative difference occurring for $Q$. alba.

Table S5 (available as Supplementary material for this paper) documents the interaction effects and main effects associated with the mean number of leaves for each factor. Consistent with the other physiological data, plants generally had more leaves in deeper, mafic soils, and this varied by species (Figs 7, 8). $Q$. michauxii (mafic soils) had the highest mean number of leaves (14.1 3.5) and $Q$. marilandica had the lowest (6.9 2.2). Figure 7 shows the interaction plot between soil type and provenance for all species, suggesting that resident seedlings had more leaves than did non-resident seedlings.

Volumetric moisture content, collected for each seedling before gas exchange measurements, is presented in Table S6. 

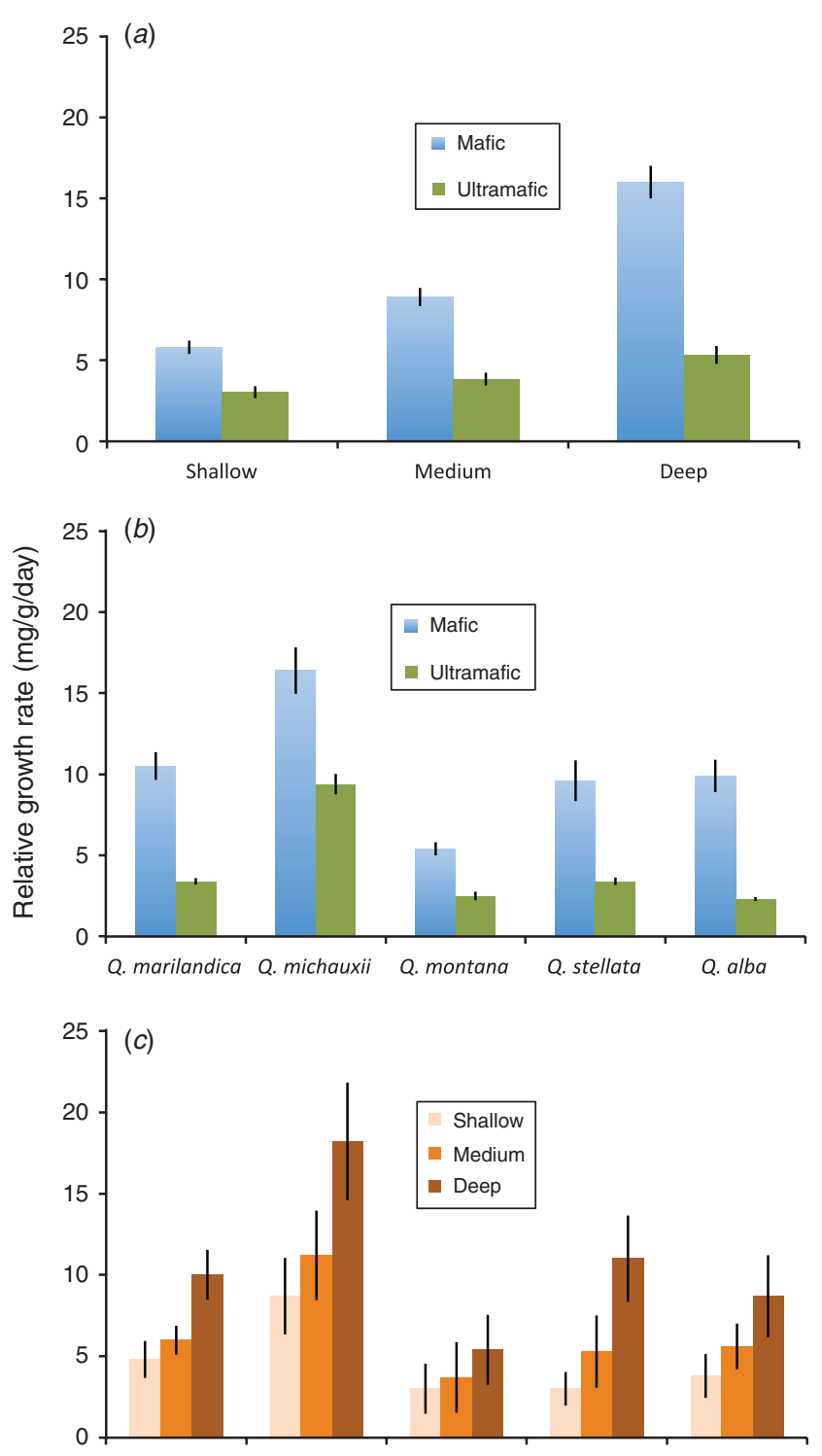

Fig. 4. Interaction plots for mean relative growth rate $\left(\mathrm{mg} \mathrm{g}^{-1}\right.$ day $\left.^{-1}\right)$, for soil type and soil depth, soil type and species, and soil depth and species. Shallow, $15 \mathrm{~cm}$; medium, $30 \mathrm{~cm}$; and deep, $60 \mathrm{~cm}$. Interactions were significant at $P \quad 0.05$. Error bars are s.e.

Soil moisture increased with soil depth in all treatments (see Table S6). Table S7 (available as Supplementary material for this paper) displays the results of a multi-way ANOVA, with both moisture content and stomatal conductance as dependent variables in response to the abiotic experimental treatments. Soil moisture and gas exchange displayed significant differences for all time measurements (with the exception of moisture in May for soil type). The only significant interaction was soil type by depth during two of the sampling periods (moisture in July and gas exchange in August).

The gas exchange and moisture measurements were examined using repeated-measures ANOVA (RMANOVA). The RMANOVA addresses how $g_{\mathrm{s}}$ and moisture differences change over time, whether there are any treatment by time interactions, and whether time is a main effect for these data. Results of the RMANOVA are given in Table S8 (available as Supplementary material for this paper). Soil type, depth and species main effects were strong and significant with respect to differences in $g_{\mathrm{s}}$, although provenance differences were not significant $(P=0.219)$. Elevated values of $g_{\mathrm{s}}$ correlate to increased carbon fixation and the values were higher in the deeper $(P<0.001)$ and mafic $(P<0.001)$ soils. The withinsubject error component of the RMANOVA showed that there was a significant time effect on gas exchange $(P<0.001)$. Significant two-way interactions occurred between time and soil depth, type and species $(P<0.001)$. All seedlings showed higher conductance in mafic and deeper soils. $Q$. marilandica and Q. stellata consistently maintained high gas exchange rates during all sampling periods, with $Q$. alba, $Q$. montana and Q. michauxii showing lower rates, respectively, in that order (Figs 9, 10). The two-way interaction between time and provenance was not significant $(P=0.086)$. No three-way interactions were significant and, as such, are not included in Table S8, for simplicity.

\section{Discussion}

Mixed oak forests sustain a diverse flora and fauna, and are highly valued for their conservation and economic attributes throughout eastern North America. However these forests have changed dramatically during the past two centuries (Dyer 2001; Abrams 2003; O'Dell et al. 2006; McEwan et al. 2011). Traditional mid-Atlantic serpentinite terranes also harbour unique mixed oak savannas, which have also declined markedly during the 20th and 21st centuries (Tyndall 1992). The oak species in the present study can be found on a wide variety of substrates and climatic conditions, and, accordingly, one might expect these oaks to display evidence of local adaptation to an environmentally heterogeneous landscape.

We examined how patterns of tree seedling mortality, growth, biomass allocation, leaf gas exchange, and leaf metal and nutritional content vary along experimental gradients of soil depth and moisture under two soil types. The experiment was conducted on seedlings growing for less than 1 year, and, as such, does not assess long-term survivorship or other larger ecological problems and may have limited microbial community differentiation. The soil types are similar with respect to common nutrients $(\mathrm{N}, \mathrm{P}, \mathrm{K})$, but are chemically imbalanced with respect to $\mathrm{Ca}: \mathrm{Mg}$ ratios, $\mathrm{Cr}$ and $\mathrm{Ni}$ content. Additionally, soils collected at the ultramafic site are shallow $(<10 \mathrm{~cm})$. When these facts are taken together, they create an edaphic system that is harsh for plants. Consistent with Abrahamson (1979), although not statistically significant, seeds for four of the five of those Quercus species collected on the ultramafic sites produced a smaller seed size than did the same species seed mass in more optimal sites (mafic), but only two of these four ( $Q$. montana and Q. alba) were statistically significant.

One might expect edaphic factors to play a fundamental role in bacterial and fungal physiology and ecology and also affect seedling performance. Soils yielded slightly higher fungal content in the ultramafic soils and no evidence of mycorrhizal colonisation in either soil type, which was likely to be due to the breakage of mycorrhizal associations during homogenisation. 

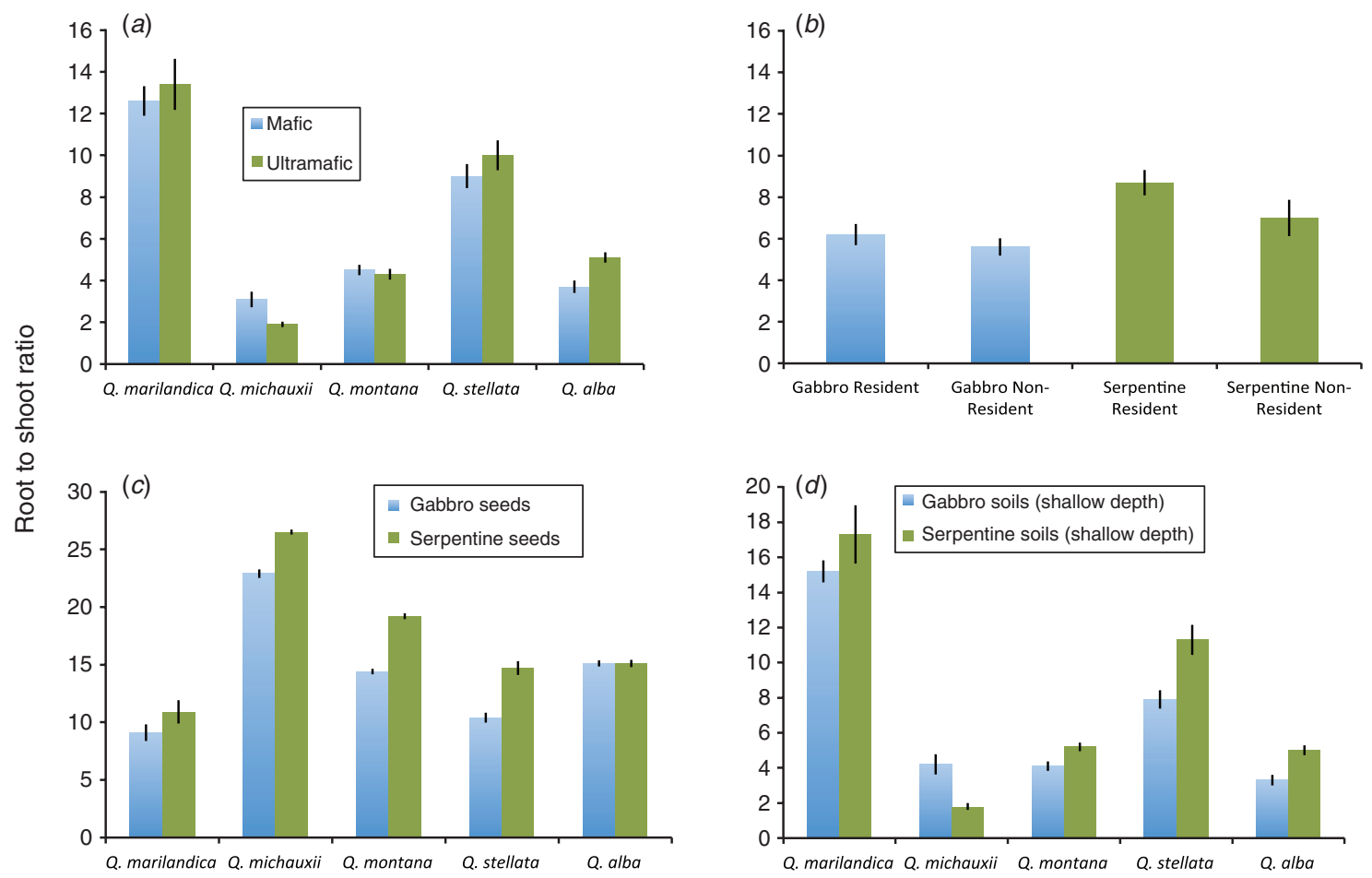

Fig. 5. Interaction plots for root to shoot ratio means, for provenance and soil type, soil type and species, soil depth and species, and provenance and species. The diagram showing soil depth, type and root to shoot mean ratios, only uses data from the $15 \mathrm{~cm}$ depth treatment. Medium and deep treatments displayed no differences. Interactions were significant at $P \quad 0.05$.

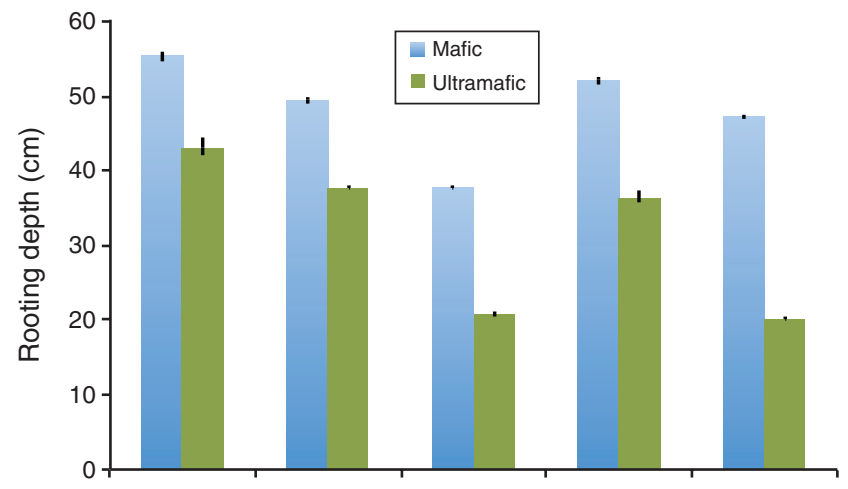

Fig. 6. Rooting depth obtained at the end of the growing season harvest for each species and soil-type treatment. Error bars are s.e.

Intense homogenisation is akin to agricultural tillage that results in fungal : bacterial ratios of $<1$ (Hendrix et al. 1986). Both soil types displayed fungal: bacterial ratios of $<1$, which suggests that fungal communities did not play a significant role in seedling performance. Grassland soils, such as those used in the present study, and early successional soils are typically bacterially dominated (Ingham et al. 1989). Mature forest soils typically have total bacterial to total fungal biomass ratios significantly greater than unity (Ingham et al. 1989). Many researchers have documented that fungi are more acid tolerant than bacteria, leading to increased fungal dominance in acidic soils (Högberg et al. 2007; Joergensen and Wichern 2008; Rousk

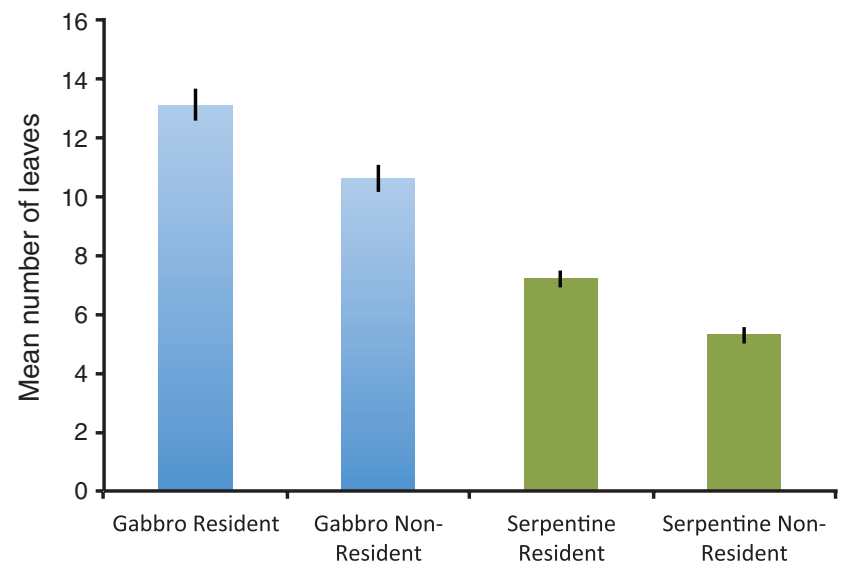

Fig. 7. Interaction plot that details the total leaf means, separated by provenance and soil type. Interactions were significant at $P \quad 0.05$. Error bars are s.e.

et al. 2009). The experimental soils were biologically neutral, perhaps partly explaining the bacterial dominance in both experimental soils.

Oak seedlings in the present study were subjected to varying levels of stress associated with soil nutritional imbalances $(\mathrm{Ca}: \mathrm{Mg})$, combined with shallow soils and concomitant lower moisture levels. Most oaks in North America have the ability to adapt to water stress through avoiding or tolerating drought (Abrams 1990). Some adaptations to drought stress are thick leaves, small stomata (Abrams 1990) and deep-penetrating root 
systems (Abrams 1990; Pallardy and Rhoads 1993). Increased stomatal conductance can help reduce leaf temperatures but with the trade-off of desiccation and cavitation. However, such

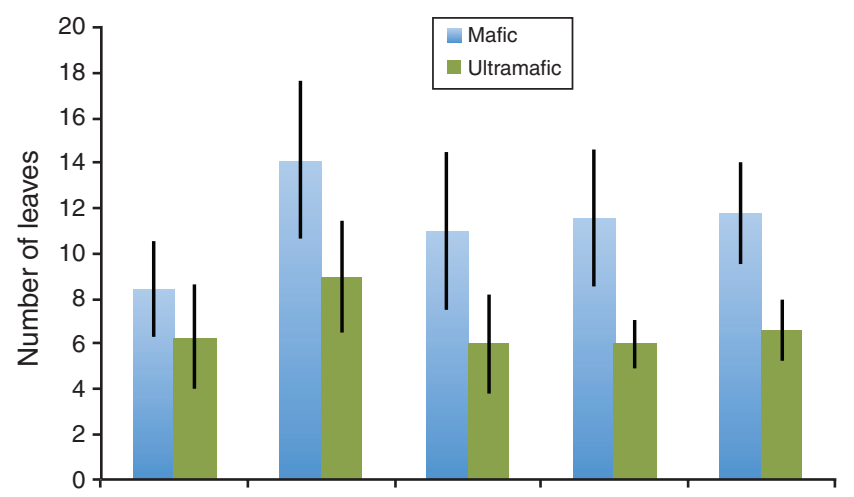

Fig. 8. Interaction plot detailing the mean number of leaves, separated by species and soil type. tolerance and traits may differ considerably among oak species and provenances, reflecting adaptation to environments with different water availability (Dickson and Tomlinson 1996) and soil fertility (Anacker et al. 2011). Edaphic stresses where woody species are exposed to high levels of toxic metals may display reduction in photosynthesis, water uptake and nutrient uptake, and may show visible symptoms of injury reflected in terms of chlorosis, growth inhibition, browning of root tips and mortality (Yadav 2010).

\section{Foliar content}

The different soil types and chemistries affected the physiological growth and leaf chemistry of the oak seedlings. Soil $\mathrm{pH}$ heavily influences plant elemental uptake, yet these two soils are both effectively neutral because of the high base cation content. The neutral $\mathrm{pH}$, combined with the lack of mycorrhizal association, may have limited metal uptake. However, there are significant differences in chemistry that were, in part, reflected in leaf concentration.

The following leaf foliar responses were observed: (i) nutrient concentrations $(\mathrm{P}, \mathrm{N}, \mathrm{K}, \mathrm{S})$ were similar regardless of soil

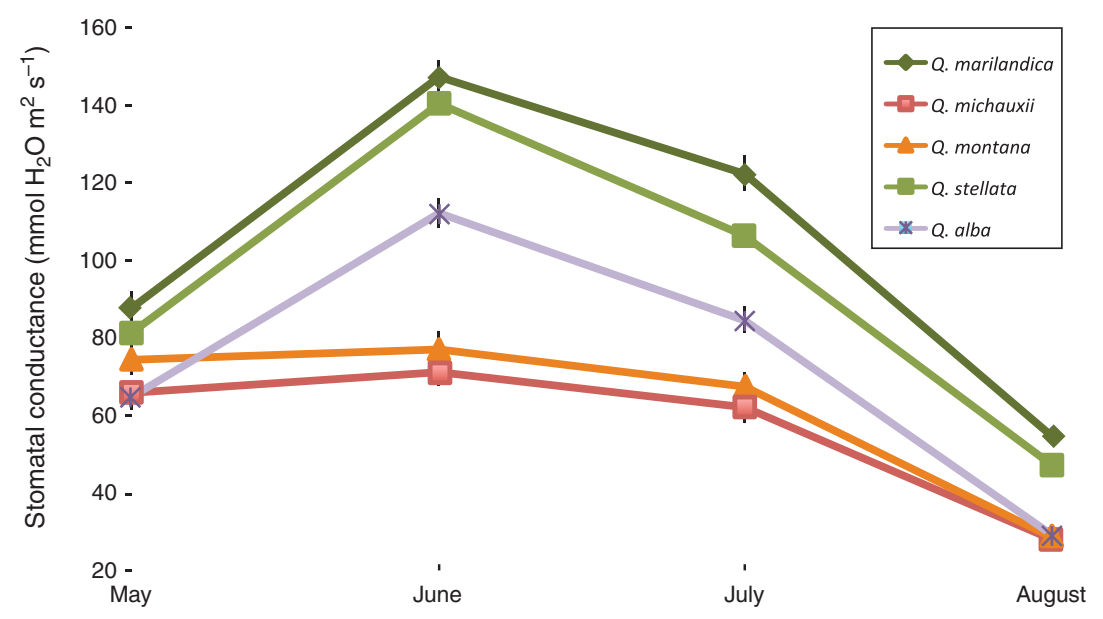

Fig. 9. Interspecific variation in mean stomatal conductance for each species over the four sampling periods. Interaction plot shows experimental tree species and mean stomatal conductance over time. Error bars are s.e. Interactions were significant at $P \quad 0.05$.

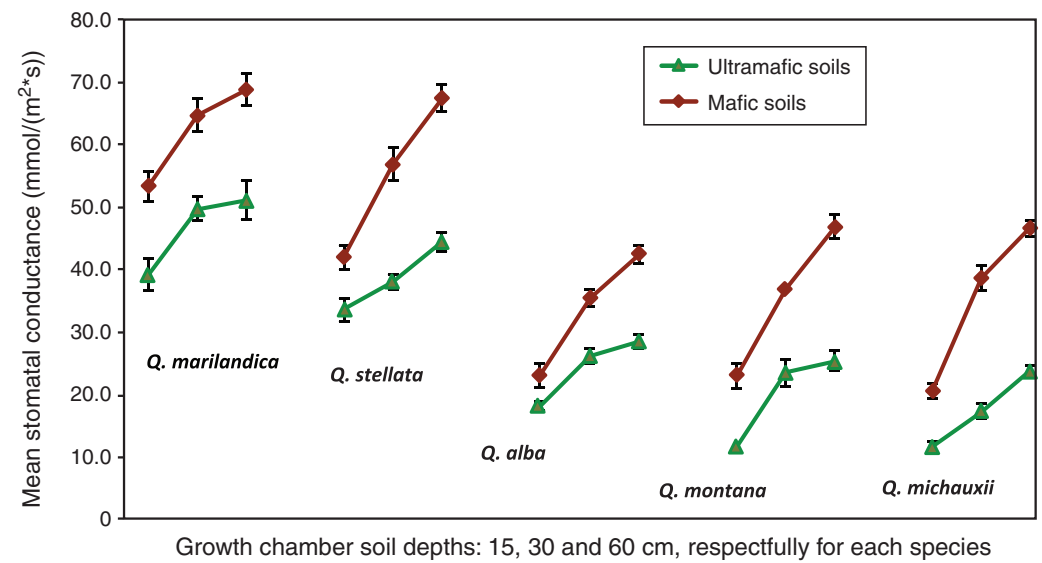

Fig. 10. Interspecific variation in mean stomatal conductance from the August dataset, separated by soil depth. Error bars are s.e. 
treatment and were significantly correlated with harvest time, (ii) $\mathrm{Ca}, \mathrm{Mg}, \mathrm{Mn}, \mathrm{Ni}$ and $\mathrm{Zn}$ are strong discriminators of the data and are shown to be sensitive to soil type and seed provenance. Considering that the ultramafic soils are generally quite depauperate in $\mathrm{Ca}$, elevated leaf $\mathrm{Ca}: \mathrm{Mg}$ ratios relative to the extremely low $\mathrm{Ca}: \mathrm{Mg}$ ratios in the serpentine soils suggest selective $\mathrm{Ca}$ uptake and that the more mesic of these species have an increased metabolic need for $\mathrm{Ca}$, whereas $Q$. stellata and Q. marilandica can grow in more Ca-poor areas, such as serpentine terrains. This translocation to the leaves and the inhibited $\mathrm{Mg}$ translocation and subsequent sequestration by roots, may be important adaptations for these species (O'Dell and Rajakaruna 2011). O'Dell et al. (2006) noted similar adaptations in Californian serpentine species, Mn appears readily transferred from soils to leaves, which is not surprising, considering that it is a physiologically active component for photosynthesis (Römheld and Marschner 1991). Similar chemistry on several serpentine oaks shows that $\mathrm{Mn}$ is readily translocated from roots to shoot (O'Dell et al. 2006). Accumulations of $\mathrm{Ni}$ may have the evolutionary advantage of protection against herbivores as well as allelopathy (Boyd and Martens 1998; Kazakou et al. 2008). Chromium, a signature element in ultramafic soils, has transfer efficiencies considerably less than unity, indicating active exclusion mechanisms and (or) uptake, consistent with the very low solubility or bioavailability of $\mathrm{Cr}$ in these soils (Vithanage et al. 2014).

Many elements that displayed significant differences in the statistical analysis, such as Li and boron (B), even though plants take them up, give no indication of being major players in serpentine environments. For example, $\mathrm{Li}$ appears not to be required for plant growth and development. However, this question is not yet completely resolved, because, in the $\mu \mathrm{g}$ $\mathrm{kg}^{-1}$ range, stimulatory effects of $\mathrm{Li}$ on plant growth have been observed (Hawrylak-Nowak et al. 2012). Boron and other elements are required for plant growth to give structure and functionality to certain biomolecules; however, they are necessary only in minute quantities (Warington 1923; Gupta and Solanki 2013).

The relative similarity in transfer efficiencies and elemental accumulations between nutrient-rich mafic soils and the low productivity of ultramafic soils suggests that these oak species have adaptations designed to reduce nutrient losses and optimise nutrient-use efficiency in diverse settings, including in harsh serpentine areas.

\section{Seedling growth}

The following general growth responses were observed: (1) seedlings derived from plants growing in serpentine soils had higher survival than seedlings derived from plants growing in mafic habitats, when both sets of seedlings were grown in serpentine soils, (2) shoot growth was reduced in shallow soils and serpentine soils, (3) RGR was species specific, but generally enhanced in mafic and deep soils, (4) Q. michauxii and Q. montana, respectively, had the highest and lowest relative growth rates of the species, (5) $Q$. marilandica and $Q$. stellata shoot height, relative growth rate and root: shoot ratio main effects and interactions with soil type are suggestive of local adaptation to soils, (6) elevated root: shoot ratios were apparent in serpentine and shallow soils, (7) root elongation was more prevalent in mafic soils, and (8) mean leaves per plant suggest that resident seedlings grown in their native or local soils have higher growth rates.

Each species exhibited unique physiological responses to the soil resource base, but some trends are apparent. The differential mortality between seedlings derived from ultramafic systems $(6.7 \%)$ and those from mafic soil systems $(0.8 \%)$, when both were planted in ultramafic soils, suggests a local ecotypic effect. Edaphic properties (physical or chemical) were the likely drivers of any such effect. Quercus marilandica and Q. stellata seedlings allocated more carbon to root systems, whereas RGRs and stem heights were lower than those for $Q$. michauxii, equal to those for $Q$. alba and greater than those for $Q$. montana. This allocation to storage and slow growth rate is an effective strategy of drought tolerance and can mediate the impacts of other stressors such as nutrient deficiency (Abrams 1990) and is consistent with traitmediated systems (Cornwell and Ackerly 2009). Oaks generally allocate more carbon to roots than do other tree species in the region. For instance, from greenhouse data, the root : shoot ratio of seedlings of Liriodendron tulipifera L. (tulip poplar) is 0.37 (Kolb et al. 1990; Loats and Rebbeck 1999), Acer rubrum L. (red maple) 0.39, and Fagus grandifolia Ehrh (American beech) 0.52 (Loach 1970). In the present study, root: shoot ratios of all oak seedlings were greater than one, with $Q$. stellata and $Q$. marilandica having the highest ratios of 9.5 and 13 , respectively. Allocating more $\mathrm{C}$ to the root system helps maintain a positive water balance during dry periods and ensures the plants are well adapted to shallow soils. Of course, maternal effects can influence the results of local-adaptation studies; however, with the long-lived oaks, time constraints on experimental duration do not typically allow for direct fitness examination of offspring (Mousseau and Fox 1998; Wright and Stanton 2011; Bieger et al. 2014).

Shallow soils had the general effect of eliciting higher root: shoot ratios and lower RGRs. Such soils would further constrain root development with concomitant loss of fixed carbon. Shallow soil usually limits water-holding capacity, intensifying environmental filtering. Thus, the more xericoriented species would require a higher root: shoot allocation to mitigate the inherent low moisture content of shallow serpentine soils. Moisture stored at depth would favour deeprooted woody plants (Walter and Mueller-Dombois 1971; Walker and Noy-Meir 1982), but such water storage is not possible in serpentine areas with extremely shallow soil profiles underlain by bedrock.

\section{Stomatal conductance}

Stomatal conductance is a measure of gas exchange reflecting how many stomata, and to what extent, are open. Plants that undergo drought stress often have a decreased $g_{\mathrm{s}}$ compared with plants not exposed to drought stress (Balok and Hilaire 2002). Figure 10 details how seedlings in this experiment consistently have lower conductance for all species in the shallow soil treatments, which also had the lowest moisture content. The following summarises the gas exchange response: (1) gas exchange was significantly higher for seedlings in nutrient-rich mafic soils and deeper soils; (2) conductance changed dramatically over the sampling period, with the lowest $g_{\text {s }}$ values during the warmer drier late summer period; and (3) 
species responded consistently, although differently, over time, with $Q$. marilandica and $Q$. stellata consistently exhibiting higher gas exchange rates. Many plants from xeric provenances have the ability to transpire and survive even when soil moisture is low. The higher $g_{\mathrm{s}}$ values indicate that the plant is under less stress; however, water leaves the leaf through the stomata, so greater $g_{\mathrm{s}}$ would increase water loss. Although seemingly a paradox, a greater $g_{\mathrm{s}}$ allows plants the ability to cool themselves and maintain a lower leaf temperature, thereby limiting losses caused by transpiration.

\section{Conclusions}

Results from this reciprocal transplant study showed that initial seedling growth of five common upland oak species from eastern USA can be considerably different. The oak species responded differently to changes in soil depth, nutrient content (soil type) and seed environmental origin. Transfer efficiencies for the elements from soil to leaf are highly correlated across species and soil treatments, with perhaps minor deviations for the elements $\mathrm{Ca}, \mathrm{Mg}$ and $\mathrm{Ni}$ for the serpentine savanna species. Quercus marilandica and Q. stellata displayed significantly higher efficiencies for the critical element $\mathrm{Ca}$. Seedlings, regardless of seed origin, soil depth or species displayed more robust growth in mafic than in ultramafic soils. Soil depth was also an important determinant of increased plant growth, with all species having greater growth in the deeper-soil treatments. Accordingly, the present study suggests the following ranking of species from more xeric-adapted to less xeric-adapted: $Q$. marilandica $>Q$. stellata $>Q$. montana Q. alba $>Q$. michauxii.

Stomatal conductance indicates that seedlings were more stressed in shallow and serpentine soils, with a clear species hierarchy for maintaining gas exchange during dry conditions. Evidence from interaction effects concerning the stomatal conductance, number of leaves and shoot height (both proxies for plant fitness) supported the hypothesis of local adaptation, at least at the seedling stage. These data have implications for serpentine-savanna restoration efforts and for managing deciduous mixed oak forests. Seedlings for planting should be derived from a local source with similar ecophysical settings. Additionally, these data indicated that as serpentinite savanna soils mature and thicken in response to woody encroachment, the more mesic oaks, Q. alba, Q. montana and $Q$. michauxii, might become competitively superior to slower-growing Q. marilandica.

\section{Funding}

Our work was funded by the National Science Foundation (DEB-0423476 and DEB-1027188) and grants from the R. Balk and D. Elliott Field Fund (Johns Hopkins University).

\section{Conflicts of interest}

No conflicts of interest.

\section{Acknowledgements}

We thank Drs Bruce Marsh and Steven Lev for use of their elemental and XRF facilities. We also thank Dr David Veblen, Michael Bernard, and two anonymous reviewers for numerous constructive comments and $\mathrm{Ms}$ Megan Zepp for invaluable help in the laboratory.

\section{References}

Abrahamson WG (1979) A comment on vegetative and seed reproduction in plants. Evolution 33, 517-519. doi:10.2307/2407641

Abrams MD (1990) Adaptations and responses to drought in Quercus species of North America. Tree Physiology 7, 227-238. doi:10.1093/treephys/7.1-2-3-4.227

Abrams MD (2003) Where has all the white oak gone? Bioscience 53, 927-939. doi:10.1641/0006-3568(2003)053[0927:WHATWO]2.0.CO;2

Ågren J, Schemske DW (2012) Reciprocal transplants demonstrate strong adaptive differentiation of the model organism Arabidopsis thaliana in its native range. New Phytologist 194, 1112-1122. doi:10.1111/j.1469-8137.2012.04112.x

Anacker BL (2014) The nature of serpentine endemism. American Journal of Botany 101, 219-224. doi:10.3732/ajb.1300349

Anacker B, Rajakaruna N, Ackerly D, Harrison S, Keeley J, Vasey M (2011) Ecological strategies in California chaparral: interacting effects of soils, climate, and fire on specific leaf area. Plant Ecology \& Diversity 4, 179-188. doi:10.1080/17550874.2011.633573

Balok CA, Hilaire RS (2002) Drought responses among seven southwestern landscape tree taxa. Journal of the American Society for Horticultural Science 127, 211-218.

Barton A, Wallenstein M (1997) Effects of invasion of Pinus virginiana on soil properties in serpentine barrens in southeastern Pennsylvania. The Journal of the Torrey Botanical Society 124, 297-305. doi: $10.2307 / 2997264$

Baythavong BS, Stanton ML (2010) Characterizing selection on phenotypic plasticity in response to natural environmental heterogeneity. Evolution 64, 2904-2920.

Bereczki K, Ódor P, Csóka G, Mag Z, Báldi A (2014) Effects of forest heterogeneity on the efficiency of caterpillar control service provided by birds in temperate oak forests. Forest Ecology and Management 327, 96-105. doi:10.1016/j.foreco.2014.05.001

Beuker E (1994) Long-term effects of temperature on the wood production of Pinus sylvestris L. and Picea abies (L.) Karst. In old provenance experiments. Scandinavian Journal of Forest Research 9, 34-45. doi:10.1080/02827589409382810

Bieger A, Rajakaruna N, Harrison S (2014) Little evidence for local adaptation to soils or microclimate in the post-fire recruitment of three Californian shrubs. Plant Ecology \& Diversity 7, 411-420. doi:10.1080/17550874.2012.701670

Boyd RS, Martens SN (1998) The significance of metal hyperaccumulation for biotic interactions. Chemoecology $8,1-7$. doi:10.1007/s000490050002

Branco S (2009) Are oaks locally adapted to serpentine soils? Northeastern Naturalist 16, 329-340. doi:10.1656/045.016.0524

Burgess JL (2013) Geologic and edaphic controls on serpentine vegetation dynamics. Thesis Dissertation, Johns Hopkins University, Baltimore, MD, USA.

Burgess JL, Szlavecz K, Rajakaruna N, Lev S, Swan CM (2015) Vegetation dynamics and mesophication in response to conifer encroachment within an ultramafic system. Australian Journal of Botany. doi:10.1071/BT14241

Carter KK (1996) Provenance tests as indicators of growth response to climate change in 10 north temperate tree species. Canadian Journal of Forest Research 26, 1089-1095. doi:10.1139/x26-120

Clausen J, Keck DD, Hiesey WM (1940) 'Experimental studies on the nature of species. I. Effect of varied environment on western North American plants.' (USA Carnegie Institution of Washington: Washington, DC)

Cornic G, Massacci A (1996) Leaf photosynthesis under drought stress. In ‘Advances in photosynthesis and respiration'. (Ed. N Baker) pp. 347-366. (Springer: Dordrecht, The Netherlands) 
Cornwell WK, Ackerly DD (2009) Community assembly and shifts in plant trait distributions across an environmental gradient in coastal California. Ecological Monographs 79, 109-126. doi:10.1890/07-1134.1

Darwin C (1859) 'On the origins of species by means of natural selection.' (Murray: London)

Davies KF, Harrison S, Safford HD, Viers JH (2007) Productivity alters the scale dependence of the diversity-invasibility relationship. Ecology $\mathbf{8 8}$, 1940-1947. doi:10.1890/06-1907.1

Dickson RE, Tomlinson PT (1996) Oak growth, development and carbon metabolism in response to water stress. Annales des Sciences Forestieres 53, 181-196. doi:10.1051/forest: 19960202

Dyer JM (2001) Using witness trees to assess forest change in southeastern Ohio. Canadian Journal of Forest Research 31, 1708-1718. doi:10.1139/x01-111

Ellison AM, Bank MS, Clinton BD (2005) Loss of foundation species: consequences for the structure and dynamics of forested ecosystems. Frontiers in Ecology and the Environment 3, 479-486. doi:10.1890/1540-9295(2005)003[0479:LOFSCF]2.0.CO;2

Ettema CH, Wardle DA (2002) Spatial soil ecology. Trends in Ecology \& Evolution 17, 177-183. doi:10.1016/S0169-5347(02)02496-5

Evans GC (1972) 'The quantitative analysis of plant growth.' (University of California Press: Oakland, CA)

Fralish JS (2004) The keystone role of oak and hickory in the central hardwood forest. Proceedings of the upland oak ecology symposium: history, current conditions, and sustainability. General Technical Report SRS-73, USDA Forest Service Southern Research Station, Asheville, NC.

Geber MA, Griffen LR (2003) Inheritance and natural selection on functional traits. International Journal of Plant Sciences 164, S21-S42. doi: $10.1086 / 368233$

Grünwald NJ, Garbelotto M, Goss EM, Heungens K, Prospero S (2012) Emergence of the sudden oak death pathogen Phytophthora ramorum. Trends in Microbiology 20, 131-138. doi:10.1016/j.tim.2011.12.006

Gupta UC, Solanki HA (2013) Impact of boron deficiency on plant growth. International Journal of Bioassays 2, 1048-1050.

Harrison SP, Rajakaruna N (2011) What have we learned from serpentine about evolution, ecology, and other sciences. In 'Serpentine: the evolution and ecology of a model system'. (Eds SP Harrison, N Rajakaruna) pp. 417-427. (University of California Press: Berkeley, CA)

Harrison S, Safford HD, Grace JB, Viers JH, Davies KF (2006) Regional and local species richness in an insular environment: serpentine plants in California. Ecological Monographs 76, 41-56. doi:10.1890/05-0910

Hawrylak-Nowak B, Kalinowska M, Szymanska M (2012) A study on selected physiological parameters of plants grown under lithium supplementation. Biological Trace Element Research 149, 425-430. doi:10.1007/s12011-012-9435-4

Heikinheimo O (1949) Tuloksia kuusen ja männyn maantieteellisillä roduilla suoritetuista kokeista. Communicationes Instituti Forestalis Fenniae 37, 1-44.

Hendrix PF, Parmelee RW, Crossley DA, Coleman DC, Odum EP, Groffman PM (1986) Detritus food webs in conventional and no-tillage agroecosystems. Bioscience 36, 374-380. doi:10.2307/1310259

Hereford J, Winn AA (2008) Limits to local adaptation in six populations of the annual plant Diodia teres. New Phytologist 178, 888-896. doi:10.1111/j.1469-8137.2008.02405.x

Hermans C, Hammond JP, White PJ, Verbruggen N (2006) How do plants respond to nutrient shortage by biomass allocation? Trends in Plant Science 11, 610-617. doi:10.1016/j.tplants.2006.10.007

Högberg MN, Chen Y, Högberg P (2007) Gross nitrogen mineralisation and fungi-to-bacteria ratios are negatively correlated in boreal forests. Biology and Fertility of Soils 44, 363-366. doi:10.1007/s00374-007-0215-9

Hunt R (1990) 'Basic growth analysis.' (Unwin Hyman: Dordrecht, The Netherlands)
Ingham ER, Klein DA (1982) Relationship between fluorescein diacetatestained hyphae and oxygen utilization, glucose utilization, and biomass of submerged fungal batch cultures. Applied and Environmental Microbiology 44, 363-370.

Ingham ER, Coleman DC, Moore JC (1989) An analysis of food-web structure and function in a shortgrass prairie, a mountain meadow, and a lodgepole pine forest. Biology and Fertility of Soils 8, 29-37. doi:10.1007/BF00260513

Joergensen RG, Wichern F (2008) Quantitative assessment of the fungal contribution to microbial tissue in soil. Soil Biology \& Biochemistry $\mathbf{4 0}$, 2977-2991. doi:10.1016/j.soilbio.2008.08.017

Johnson KD, Scatena FN, Johnson AH, Pan Y (2009) Controls on soil organic matter content within a northern hardwood forest. Geoderma 148, 346-356. doi:10.1016/j.geoderma.2008.11.002

Kawecki TJ, Ebert D (2004) Conceptual issues in local adaptation. Ecology Letters 7, 1225-1241. doi:10.1111/j.1461-0248.2004.00684.x

Kay KM, Ward KL, Watt LR (2011) Plant speciation. In 'Serpentine: the evolution and ecology of a model system'. (Eds SP Harrison, N Rajakaruna) pp. 71-96. (University of California Press: Berkeley, CA)

Kazakou E, Dimitrakopoulos PG, Baker AJM, Reeves RD, Troumbis AY (2008) Hypotheses, mechanisms and trade-offs of tolerance and adaptation to serpentine soils: from species to ecosystem level. Biological Reviews of the Cambridge Philosophical Society 83, 495-508.

Kolb TE, Steiner KC, McCormick LH, Bowersox TW (1990) Growth response of northern red-oak and yellow-poplar seedlings to light, soil moisture and nutrients in relation to ecological strategy. Forest Ecology and Management 38, 65-78. doi:10.1016/0378-1127(90)90086-Q

Kruckeberg AR (1986) An essay: the stimulus of unusual geologies for plant speciation. Systematic Botany 11, 455-463. doi:10.2307/2419082

Lechowicz MJ, Bell G (1991) The ecology and genetics of fitness in forest plants. II. Microspatial heterogeneity of the edaphic environment. Journal of Ecology 79, 687-696. doi:10.2307/2260661

Leimu R, Fischer M (2008) A meta-analysis of local adaptation in plants. PLOS ONE 3(12), e4010. doi:10.1371/journal.pone.0004010

Linhart YB, Grant MC (1996) Evolutionary significance of local genetic differentiation in plants. Annual Review of Ecology and Systematics 27, 237-277. doi:10.1146/annurev.ecolsys.27.1.237

Loach K (1970) Shade tolerance in tree seedlings. New Phytologist 69, 273-286. doi:10.1111/j.1469-8137.1970.tb02426.x

Loats KV, Rebbeck J (1999) Interactive effects of ozone and elevated carbon dioxide on the growth and physiology of black cherry, green ash, and yellow-poplar seedlings. Environmental Pollution 106, 237-248. doi:10.1016/S0269-7491(99)00069-X

Lorimer CG (1993) Causes of the oak regeneration problem. Oak regeneration: serious problems, practical recommendations. USDA Forest Service general technical report SE-84, Southeastern Forest Experiment Station, Asheville, NC.

McEwan RW, Dyer JM, Pederson N (2011) Multiple interacting ecosystem drivers: toward an encompassing hypothesis of oak forest dynamics across eastern North America. Ecography 34, 244-256. doi:10.1111/j.1600-0587.2010.06390.x

McShea WJ, Healy WM, Devers P, Fearer T, Koch FH, Stauffer D, Waldon J (2007) Forestry matters: decline of oaks will impact wildlife in hardwood forests. The Journal of Wildlife Management 71, 1717-1728. doi:10.2193/2006-169

Moore KA, Elmendorf SC (2011) Plant competition and facilitation in systems with strong environmental gradients. In 'Serpentine: the evolution and ecology of a model system'. (Eds SP Harrison, N Rajakaruna) pp. 223-236. (University of California Press: Berkeley, CA)

Mousseau TA, Fox CW (1998) The adaptive significance of maternal effects. Trends in Ecology \& Evolution 13, 403-407. doi:10.1016/S0169-5347(98)01472-4

Nowacki GJ, Abrams MD (1992) Community, edaphic, and historical analysis of mixed oak forests of the Ridge and Valley Province in 
central Pennsylvania. Canadian Journal of Forest Research 22, 790-800. doi:10.1139/x92-108

O’Dell RE, Rajakaruna N (2011) Intraspecific variation, adaptation, and evolution. In 'Serpentine: the evolution and ecology of a model system'. (Eds SP Harrison, N Rajakaruna) pp. 97-137. (University of California Press: Berkeley, CA)

O'Dell RE, James JJ, Richards JH (2006) Congeneric serpentine and nonserpentine shrubs differ more in leaf $\mathrm{Ca}: \mathrm{Mg}$ than in tolerance of low N, low P, or heavy metals. Plant and Soil 280, 49-64. doi:10.1007/s11104-005-3502-y

Pallardy SG, Rhoads JL (1993) Morphological adaptations to drought in seedlings of deciduous angiosperms. Canadian Journal of Forest Research 23, 1766-1774. doi:10.1139/x93-223

Rajakaruna N (2004) The edaphic factor in the origin of plant species. International Geology Review 46, 471-478. doi:10.2747/0020-6814.46.5.471

Rajakaruna N, Bradfield GE, Bohm BA, Whitton J (2003) Adaptive differentiation in response to water stress by edaphic races of Lasthenia californica (Asteraceae). International Journal of Plant Sciences 164, 371-376. doi:10.1086/368395

R Core Team (2013) 'R: A language and environment for statistical computing.' (R Foundation for Statistical Computing: Vienna, Austria) Available at: http://www.R-project.org/

Rehfeldt GE, Ying CC, Spittlehouse DL, Jr DAH (1999) Genetic responses to climate in Pinus contorta: niche breadth, climate change, and reforestation. Ecological Monographs 69, 375-407. doi:10.1890/0012-9615(1999)069[0375:GRTCIP]2.0.CO;2

Rehfeldt GE, Tchebakova NM, Parfenova YI, Wykoff WR, Kuzmina NA, Milyutin LI (2002) Intraspecific responses to climate in Pinus sylvestris. Global Change Biology 8, 912-929. doi:10.1046/j.1365-2486.2002.00516.x

Reich PB, Wright IJ, Cavender-Bares J, Craine JM, Oleksyn J, Westoby M, Walters MB (2003) The evolution of plant functional variation: traits, spectra, and strategies. International Journal of Plant Sciences 164, S143-S164. doi:10.1086/374368

Rice KJ, Mack RN (1991) Ecological genetics of Bromus tectorum. Oecologia 88, 91-101. doi:10.1007/BF00328408

Römheld V, Marschner H (1991) Function of micronutrients in plants. In 'Micronutrients in agriculture'. 2nd edn. SSSA Book Series, No. 4. (Eds JJ Mordvedt, FR Cox, LM Shuman, RM Welch) pp. 297-328. (SSSA: Madison, WI)

Rousk J, Brookes PC, Bååth E (2009)Contrasting soil pH effects on fungal and bacterial growth suggest functional redundancy in carbon mineralization. Applied and Environmental Microbiology 75, 1589-1596. doi:10.1128/AEM.02775-08

Savolainen O, Pyhäjärvi T, Knürr T (2007) Gene flow and local adaptation in trees. Annual Review of Ecology Evolution and Systematics 38, 595-619. doi:10.1146/annurev.ecolsys.38.091206.095646

Schedlbauer JL, Pistoia VL (2013) Water relations of an encroaching vine and two dominant $\mathrm{C}_{4}$ grasses in the serpentine barrens of southeastern Pennsylvania 1. The Journal of the Torrey Botanical Society 140, 493-505. doi:10.3159/TORREY-D-13-00010.1
Schluter D (2009) Evidence for ecological speciation and its alternative. Science 323, 737-741. doi: $10.1126 /$ science. 1160006

Selmants PC, Zavaleta ES, Pasari JR, Hernandez DL (2012) Realistic plant species losses reduce invasion resistance in a California serpentine grassland. Journal of Ecology 100, 723-731. doi: 10.1111/j.1365-2745.2011.01949.x

Shaw JN, West LT, Hajek BF (2001) $\mathrm{Ca}-\mathrm{Mg}$ ratios for evaluating pedogenesis in the piedmont province of the southeastern United States of America. Canadian Journal of Soil Science 81, 415-421. doi:10.4141/S00-045

Shutyaev AM, Giertych M (2000) Genetic subdivisions of the range of Scots pine (Pinus sylvestris L.) based on a transcontinental provenance experiment. Silvae Genetica 49, 137-151.

Siegwart Collier LCS, Mallik AU (2010) Does post-fire abiotic habitat filtering create divergent plant communities in black spruce forests of eastern Canada? Oecologia 164, 465-477. doi:10.1007/s00442-010-1642-0

Tyndall RW (1992) Historical considerations of conifer expansion in Maryland serpentine' barrens'. Castanea 57, 123-131.

van der Putten WH, de Ruiter PC, Bezemer TM, Harvey JA, Wassen M, Wolters V (2004) Trophic interactions in a changing world. Basic and Applied Ecology 5, 487-494. doi:10.1016/j.baae.2004.09.003

Vithanage M, Rajapaksha A, Oze C, Rajakaruna N, Dissanayake CB (2014) Metal release from serpentine soils in Sri Lanka. Environmental Monitoring and Assessment 186, 3415-3429. doi:10.1007/s10661-014-3626-8

Walker BH, Noy-Meir I (1982) Aspects of the stability and resilience of savanna ecosystems. In 'Aspects of the stability and resilience of savanna ecosystems'. (Eds BJ Huntley and BH Walker) pp. 556-590. (Springer-Verlag: Berlin)

Walter H, Mueller-Dombois D (1971) 'Ecology of tropical and subtropical vegetation.' (Oliver \& Boyd: Edinburgh, UK)

Wardle DA, Bardgett RD, Klironomos JN, Setälä H, van der Putten WH, Wall DH (2004) Ecological linkages between aboveground and belowground biota. Science 304, 1629-1633. doi:10.1126/science.1094875

Warington K (1923) The effect of boric acid and borax on the broad bean and certain other plants. Annals of Botany 37, 629-672.

Whittaker RH (1954) The ecology of serpentine soils. Ecology 35, 258-288. doi: $10.2307 / 1931126$

Wright JW (2007) Local adaptation to serpentine soils in Pinus ponderosa. Plant and Soil 293, 209-217. doi:10.1007/s11104-006-9181-5

Wright JW, Stanton ML (2011) Local adaptation in heterogeneous landscapes. In 'Serpentine: the evolution and ecology of a model system'. (Eds SP Harrison, N Rajakaruna) pp. 155-179. (University of California Press: Berkeley, CA)

Yadav SK (2010) Heavy metals toxicity in plants: an overview on the role of glutathione and phytochelatins in heavy metal stress tolerance of plants. South African Journal of Botany 76, 167-179. doi:10.1016/j.sajb.2009.10.007

Yost JM, Barry T, Kay KM, Rajakaruna N (2012) Edaphic adaptation maintains the coexistence of two cryptic species on serpentine soils. American Journal of Botany 99, 890-897. doi:10.3732/ajb.1100521 